\title{
Capital Flows and Real Exchange Rate Fluctuations Following Spain's Entry into the European Community
}

\author{
Gonzalo Fernandez de Cordoba* \\ Departamento de Economía e Historia Económica, Universidad de Salamanca \\ Campus Miguel de Unamuno, 37008 Salamanca, Spain
}

Timothy J. Kehoe ${ }^{\dagger}$

Department of Economics, University of Minnesota

271 19th Avenue South, Minneapolis, Minnesota 55455, United States

and

Research Department, Federal Reserve Bank of Minneapolis,

90 Hennepin Avenue, Minneapolis, Minnesota 55401, United States

November 1998

Revised May 1999

(C)1999, Gonzalo Fernandez de Cordoba and Timothy J. Kehoe

Classification codes: C68, F41.

Key words: Spain, international factor movements, nontraded goods, real exchange rate, adjustment costs.

\begin{abstract}
Spain's 1986 entry into the European Community was followed by a dismantling of restrictions on international capital flows. Initial trade deficits and real exchange rate appreciation were followed by trade surpluses and real exchange rate depreciation. This paper analyzes Spain's financial liberalization using a dynamic general equilibrium model with a traded and nontraded good where a capital poor country opens itself to its capital rich neighbors. A carefully calibrated model has trouble accounting for the large changes in relative prices observed given the small changes in quantities. Variants of the model with frictions in factor mobility between sectors fare better.

\footnotetext{
${ }^{*}$ We are grateful to participants at the III Workshop on Dynamic Macroeconomics at the Universidade de Vigo, the 1998 Summer Camp in International Macroeconomics at the Universidad Torcuato di Tella, the 1998 Meeting of the Latin American and Caribbean Economics Association, and seminars at the Federal Reserve Bank of Minneapolis and the Universitat Pompeu Fabra for helpful comments, especially Caroline Betts, Michele Boldrin, Jordi Gali, Kenneth Kletzer, David Levine, Albert Marcet, Enrique Mendoza, and Carlos Vegh. Patrick Kehoe provided guidance and encouragement at a crucial stage. The National Science Foundation and the McKnight Foundation provided financial support. The views expressed herein are those of the authors and not necessarily those of the Federal Reserve Bank of Minneapolis or the Federal Reserve System.

${ }^{\dagger}$ Corresponding author: 1-612-625-1589 (office), 1-612-624-0209 (fax), tkehoe@atlas.socsci.umn.edu (e-mail).
} 


\section{Introduction}

On 1 January 1986 Spain entered what was then the European Community and began to dismantle its restrictions on international capital flows. Before 1986 the Spanish government had placed few restrictions on foreign investment, but there were severe restrictions on the repatriation of earnings out of Spain. In addition, there were restrictions on the operations of foreign financial intermediaries that had to be dismantled, at least in the case of financial intermediaries from other EC countries, over a seven year period, starting in 1986.

Following Spain's entry into the European Community, its economy experienced a consumption boom and an investment boom that lasted until 1992. There were trade deficits that reached a peak of over 3 percent of GDP in 1989-1991. Furthermore, the Spanish peseta appreciated substantially in real terms against the currencies of Spain's major European trading partners. The peseta/deutsche mark real exchange rate, for example, appreciated almost 30 percent by 1991 . Starting in 1992, however, the process reversed itself: Investment and the trade deficit fell sharply. The real exchange rate depreciated.

This paper investigates the extent to which these events can be explained as the equilibrium outcomes of a dynamic general equilibrium model where a relatively capital poor country opens itself to its relatively capital rich neighbors. The key ingredient that links capital flows to real exchange rate fluctuations is the need for nontraded goods both in consumption and in investment.

The model used in this paper is fairly standard in the literature: Turnovsky (1997) presents a number of variants of this sort of model, which he calls the dependent economy model, and provides a wealth of references. Engel and Kletzer (1989) point out that a dynamic general equilibrium model would predict trade deficits followed by trade surpluses after financial liberalization in a relatively capital poor country. Mendoza and Uribe (1996), Rebelo (1993), and Rebelo and Vegh (1995) apply this sort of model to the analysis of different exchange rate policies.

The paper takes the model, calibrates it carefully to data from the Spanish economy, and asks whether the model is able to produce results that are not wildly inconsistent with the Spanish experience. The Spanish experience is interesting because of its similarities to the experiences of other countries that have undergone financial liberalizations, like Argentina, Brazil, Chile, Mexico, and Portugal. Unlike these other countries, however, whose experiences have been studied by researchers like Rebelo (1993) and Rebelo and Vegh (1995), Spain provides a fresh dataset to be studied. Although the model used in the paper is fairly standard, its application to explaining the Spanish experience is somewhat radical. More conventional explanations, such as that of Ayuso and Escrivá (1998), focus on monetary policy and nominal exchange rate policy. These sorts of nominal factors are ignored in this paper.

In the next section, we look at the data to estimate the total size of capital flows that we would have expected to see following Spanish financial liberalization. Using data on output per worker and capital per worker from Summers and Heston (1991), we make rough calculations of how much of the differences in output per worker between Spain and Germany is due to more capital per worker in Germany and how much is due to higher total factor productivity in Germany. We also investigate the extent to which the movements in the Spanish real exchange rate can be explained by changes in the relative prices of nontraded goods to those of traded goods. We find that only about 26 percent of real exchange rate fluctuations are due to changes in these relative prices. Since changes in the relative price of the single nontraded good to that of the single trade good are the only source of real exchange rate fluctuations in our model, it is only this 26 percent of total fluctuations that the model can hope to account for.

The third, fourth, and fifth sections present the model, its calibration, and a base case sim- 
ulation. Spain is modeled as a small open economy that is initially closed. We use the 1986 input-output matrix for Spain to calibrate the parameters of the model. Although the variables all move in the right direction following financial liberalization, the exercise is a quantitative failure: capital flows in the simulation are far too rapid, and real exchange rate fluctuations are far too small.

In section 6 , we investigate the causes of the failure of the model. Given that the data tells us the extent to which quantities moved following financial liberalization, we find that small response in relative prices is due of a lack of sufficient curvature in the production possibilities frontier.

One way to put curvature into the production possibilities frontier in the short run is to put frictions into the movement of capital and labor between the traded sector and the nontraded sector. These frictions also slow down foreign capital inflows. In section 7 , we impose these frictions and investigate their implications on such other variables as output, employment, and wages by sector. Our results suggest that frictions on both capital movements and labor movements are important, and that a model with such frictions can account for most of the capital flows and most of the real exchange rate appreciation due to changes in the relative prices of nontraded goods.

Section 8 concludes with suggestions for future research.

\section{Capital Flows and Real Exchange Rate Fluctuations}

This section makes two points that we need to keep in mind when we calibrate our model: First, given the observed differences in output per worker and capital per worker between Spain and such neighbors as Germany before 1986, we should have expected to see huge capital inflows following financial liberalization. Second, in trying to explain real exchange rate fluctuations as the result of changes in the nontraded/traded relative prices, we need to look at direct measures of how these relative prices changed. In the model that we develop subsequently, there is only one traded good, and it is only the part of real exchange rate fluctuations explained by changes in the nontraded/traded relative price, which we refer to as explained real exchange rate fluctuations, that we can hope to account for.

Turning first to capital flows, we can do the same sort of back-of-the-envelope calculations as Lucas (1990) to see the extent to which the differences in output per workers observed between Spain and Germany can be explained by observed differences in capital per worker. Although these observed differences play an important role in our analysis, our model is silent about the causes of the relatively low level of the Spanish capital stock in 1986. A quick read of recent Spanish economic history suggests that political risk and a misguided industrial policy played important roles (see, for example, Harrison, (1995) and Salmon, (1995)).

Suppose that output in both Spain and Germany is produced by a single sector, with the same Cobb-Douglas production functions in each country:

$$
Y_{j}=A K_{j}^{\alpha} N_{j}^{1-\alpha}, \quad j=\mathrm{esp}, \text { ger. }
$$

Output per worker is then a simple function of capital per worker,

$$
y_{j}=A k_{j}^{\alpha}, \quad j=\mathrm{esp}, \text { ger. }
$$

According to Summers and Heston (1991), in 1986 output per worker in Spain was $y_{e s p}=21,875$ 1985 international dollars and capital per worker was $k_{e s p}=45,305$. In Germany these same 
data were $y_{g e r}=27,897$ and $\mathrm{k}_{g e r}=73,618$. (Our measure of capital, taken from the Summers, Heston, Aten, and Nuxoll, 1995 diskette includes nonresidential capital, residential construction, and transportation equipment.) Given the observed differences in capital per worker, we would expect output per worker to satisfy the relationship

$$
\frac{y_{e s p}}{y_{g e r}}=\left(\frac{k_{e s p}}{k_{g e r}}\right)^{\alpha}=(0.6154)^{\alpha} .
$$

If we use the value $\alpha=0.3020$ that we calibrate from Spanish data in section 4 , we would expect the ratio of output per worker in Spain to that in Germany to be 0.8636. In the data it is 0.7846 .

In contrast to the comparison of India and the United States made by Lucas (1990) and that of Mexico and the rest of North America made by Kehoe (1995), the difference in capital per worker between Spain and Germany accounts for more than half, about 63 percent, of the differences in output per worker. We can calibrate different constants $A_{\mathrm{j}}, j=\mathrm{esp}$, ger, so as to match the observed $y_{j}$ and $k_{j}$ :

$$
\begin{aligned}
& A_{\text {esp }}=y_{\text {esp }} / k_{\text {esp }}^{\alpha}=858.6021 \\
& A_{\text {ger }}=y_{\text {ger }} / k_{\text {ger }}^{\alpha}=945.0353 .
\end{aligned}
$$

In other words, to explain the remaining 37 percent of the difference in output per worker between Spain and Germany, total factor productivity needs to be about 10 percent higher in Germany. (As we later point out, however, we are still left with the mystery of why real interest rates were not much higher in Spain in the early 1980s than they were in Germany.)

We can now calculate the increase in the Spanish capital stock that would equalize the rental rates of capital in Spain and in Germany:

$$
\alpha A_{\mathrm{esp}} k_{\mathrm{esp}}^{\alpha-1}=\alpha A_{\mathrm{ger}} k_{\mathrm{ger}}^{\alpha-1} .
$$

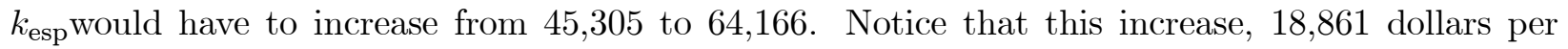
worker, is about 86 percent of Spanish GDP and about 42 percent of the Spanish capital stock. This implies that, in a one sector model with no frictions and Spain modeled as an open economy, we would expect to see a financial liberalization accompanied by massive trade deficit in the first period as Spain imports capital goods. The trade deficit would actually be larger than 86 percent of GDP because Spanish workers, knowing that they would receive higher wages once this capital is in place, would borrow to smooth consumption. From the second period of the model on, Spain would be in a steady state with a large trade surplus necessary to service its debt.

One way to slow down capital inflows in the model is to distinguish between traded goods and nontraded goods that are used in both investment and consumption. As a capital poor country opens itself financially, there is still an investment boom and a consumption boom. Traded goods can be imported, but nontraded goods, like factories and residential housing, must be produced domestically. As in figure 1, as production shifts from traded to nontraded goods, the relative price of non traded goods increases. This makes investment goods relatively expensive compared to what they will cost later, slowing down investment. The increase in the relative price of the non traded good also produces an increase in the real exchange rate. We now argue that a significant fraction (albeit well less than half) of the fluctuations in the peseta/deutsche mark real exchange 
rate over the period 1986-1996 was, in fact, due to changes in the relative prices of non traded goods. Consider the definition of the real exchange rate:

$$
\mathrm{RER}=\mathrm{NER} \times \frac{P_{\text {ger }}}{P_{\mathrm{esp}}} .
$$

Here NER is the peseta/deutsche mark nominal exchange rate; $P_{\text {ger }}$ is a German price index; and $P_{\text {esp }}$ is a Spanish price index. The units in which RER is expressed are

$$
\begin{aligned}
\text { units } & =\frac{\text { pesetas }}{\text { deutsche mark }} \times \frac{\text { deutsche marks/German basket }}{\text { pesetas/Spanish basket }} \\
& =\frac{\text { Spanish baskets }}{\text { German basket }}
\end{aligned}
$$

A decrease in RER corresponds to a real appreciation of the peseta: fewer Spanish baskets are needed to obtain a German basket in trade. As Betts and Kehoe (1999) argue, the ideal price indices to use in this context are those for gross output. Because of problems in obtaining this data for Spain, we use instead value added deflators, which Betts and Kehoe show are close proxies for gross output deflators, at least in countries where both series are available. (See appendix for details.) Suppose that the law of one price holds for traded goods, so that

$$
P_{\text {esp }}^{T}=\mathrm{NER} \times P_{\text {ger }}^{T},
$$

where $P_{j}^{T}$ is the price index for trade goods in country $j$. Substituting equation (9) into the definition of the real exchange rate (7), we obtain

$$
\mathrm{R} \widehat{\mathrm{ER}}=\frac{P_{\mathrm{esp}}^{T}}{P_{\text {ger }}^{T}} \times \frac{P_{\text {ger }}}{P_{\mathrm{esp}}}=\frac{\left(P_{\text {ger }} / P_{\text {ger }}^{T}\right)}{\left(P_{\mathrm{esp}} / P_{\mathrm{esp}}^{T}\right)} .
$$

Since the part of the price index $P_{j}$ that is not $P_{j}^{T}$ is the price index for non traded goods, this says that the fluctuations in the real exchange rate can be explained by changes in the relative prices of nontraded goods.

We have obtained the formula for the index R $\widehat{E} R$ in (10) by assuming that equation (9) holds, that there are no changes in the terms of trade. This index tells us what real exchange rate fluctuations would be if the only determinant of these fluctuations was changes in the relative prices of nontraded goods. We refer to R $\widehat{E R}$ as the explained real exchange rate.

Figure 2 shows the peseta/deutsche mark real exchange rate over the period 1985-1996 together with the corresponding explained real exchange rate. (See the appendix for details.) Notice that the two curves move together: the correlation between the two curves over the period 1986-1996 is 0.5612 . Only a fraction of the variation in RER is explained by variations in R $\widehat{E R}$, however: absolute deviations of $\mathrm{RE} R$ from its base period value account for 0.2638 of the sum of absolute deviations of RER. Here we define the fraction of absolute deviations explained as total absolute deviations minus absolute deviations not explained, divided by total absolute deviations:

$$
R=\frac{\sum_{t=1987}^{1996}\left|\mathrm{RER}_{t}-\mathrm{RER}_{1986}\right|-\sum_{t=1987}^{1996}\left|\mathrm{RER}_{t}-\mathrm{RER}_{t}\right|}{\sum_{t=1987}^{1996}\left|\mathrm{RER}_{t}-\mathrm{RER}_{1986}\right|} .
$$

In other words, $R=0.2638$ means that 26 percent of the fluctuations in the real exchange rate is explained by changes in the relative prices of nontraded goods. In terms of the simple model with 
one traded good presented in this paper, this leaves 74 percent to be explained by changes in the relative price of this traded good across countries, the terms of trade. As Mendoza (1995) shows, with more than one traded good, we would expect some of this 74 percent to be accounted for by different compositions of output of traded goods across countries.

In the model in this paper the only source of fluctuations in the real exchange rate is changes in the relative price of the nontraded good in Spain. Consequently, it is only fluctuations in the data in figure 2 that we are capable of accounting for. It is worthwhile noting the qualitative similarities in the relationship between the two curves in figure 2 and those in the corresponding graph for the Mexican peso/U.S. dollar real exchange rate over the period 1980-1994 presented by Betts and Kehoe (1999), although a higher fraction of fluctuations in RER are explained by fluctuations in $\mathrm{R} \widehat{\mathrm{ER}}$ in the peso/dollar case.

\section{The Model}

Spain is modeled as a small open economy with a representative consumer. In each period there are five goods: a traded good, a nontraded good, labor, capital, and an investment good that augments the capital stock in the subsequent period.

The representative consumer solves the utility's maximization problem

$$
\begin{array}{ll} 
& \max \sum_{t=0}^{\infty} \beta^{t}\left(\epsilon c_{0 t}^{\rho}+(1-\epsilon) c_{1 t}^{\rho}-1\right) / \rho \\
\text { such that } \quad & c_{00}+p_{0} c_{10}+a_{1} \leq w_{0} \bar{\ell}+\nu_{0} \bar{k}_{0} \\
& c_{0 t}+p_{t} c_{1 t}+a_{t+1} \leq w_{t} \bar{\ell}+\left(1+r_{t}\right) a_{t}, \quad t=1,2, \ldots \\
& c_{0 t} \geq 0, \quad c_{1 t} \geq 0, \quad a_{t} \geq-A .
\end{array}
$$

Here, $c_{0 t}$ consumption of the traded good, which is numeraire; $c_{1 t}$ is consumption of the nontraded good and $p_{t}$ is the price of the nontraded good relative to that of the traded good; $\bar{\ell}$ is the endowment of labor, which is supplied inelastically and receives the wage $w_{t} ; a_{t+1}$ is the amount of assets purchased in period $t$ and sold in period $t+1$, earning interest $r_{t+1}$; and $v_{0}$ is the price of capital in period 0 . The utility function has the same constant elasticity of substitution, $1 /(1-\rho)$, between goods within a period and between goods across periods; in the limit where $\rho=0$ this function is, of course, logarithmic. The constraint $a_{t} \geq-A$ for $A$ sufficiently large, rules out Ponzi schemes but does not otherwise bind in equilibrium.

Assets purchased in period $t$ take the form either of physical capital or of bonds denominated in units of traded goods:

$$
a_{t+1}=q_{t} k_{t+1}+b_{t+1} .
$$

Here $q_{t}$ is the price of the investment good relative to that of the traded good; $k_{t+1}$ is the amount of capital accumulated in period $t$ for use in period $t+1$; and $b_{t+1}$ is the amount of bonds purchased in period $t$ and redeemed in period $t+1$. If $b_{t+1}$ is negative, Spain is borrowing from the rest of the world.

The model allows two alternative specifications of interstate determination and of foreign borrowing or lending: In the first specification, the economy is closed; the interest rate $r_{t}$ is determined endogenously; and there is no foreign borrowing or lending, $b_{t}=0$. In the second specification, the 
economy is open; the interest rate $r_{t}$ is equal to an exogenously given international rate, $r_{t}=r^{*}$; and foreign borrowing or lending $b_{t}$ is determined endogenously.

Both the traded good and the nontraded good are produced by Cobb-Douglas production functions that use capital and labor as inputs. In addition, the traded good can be imported from the rest of the world. The outputs of traded good and the nontraded good are consumed by the representative consumer and used as inputs into the investment sector. In addition, the traded good can be exported. The feasibility constraint for the nontraded sector is

$$
c_{1 t}+z_{1 t} \leq A_{1} k_{1 t}^{\alpha_{1}} \ell_{1 t}^{1-\alpha_{1}}
$$

where $z_{1 t}$ is the nontraded input into the investment sector, $k_{1 t}$ is the capital input into the nontraded sector, and $\ell_{1 t}$ is the labor input into the nontraded sector. The feasibility constraint for the traded sector is similar and is complicated only by the possibility of trade with the rest of the world:

$$
c_{0 t}+z_{0 t}+b_{t+1} \leq A_{0} k_{0 t}^{\alpha_{0}} \ell_{0 t}^{1-\alpha_{0}}+\left(1+r_{r}\right) b_{t} .
$$

Here $b_{t+1}-\left(1+r_{t}\right) b_{t}$ is the trade balance.

The investment good is produced using inputs of the traded good and the nontraded good, which can be thought of loosely as equipment and structures respectively:

$$
k_{t+1}-(1-\delta) k_{t} \leq G z_{0 t}^{\gamma} z_{1 t}^{1-\gamma},
$$

where $\delta$ is the rate of depreciation.

An equilibrium of this economy is sequences of prices, $\widehat{p}_{t}, \widehat{w}_{t}, \widehat{r}_{t}, \widehat{q}_{t}, \widehat{v}_{0}$, of consumption and asset accumulation, $\widehat{c}_{0 t}, \widehat{c}_{1 t}$, $\widehat{a}_{t}$, of capital stocks and net foreign asset positions, $\widehat{k}_{t}, \widehat{b}_{t}$, of sectoral production plans, $\widehat{k}_{0 t}, \widehat{\ell}_{0 t}, \widehat{k}_{1 t}, \widehat{\ell}_{1 t}$ and of inputs into the investment sector, $\widehat{z}_{0 t}, \widehat{z}_{1 t}$ such that the following conditions are satisfied:

1. Given the prices, $\widehat{p}_{t}, \widehat{w}_{t}, \widehat{r}_{t}, \widehat{q}_{t}, \widehat{\nu}_{0}$, the representative consumer chooses the consumption and asset accumulation plan $\widehat{c}_{0 t}, \widehat{c}_{1 t}, \widehat{a}_{t}$ to solve the utility maximization problem (12).

2. Given the prices $\widehat{p}_{t}, \widehat{w}_{t}, \widehat{r}_{t}, \widehat{q}_{t}, \widehat{v}_{0}$, producers in the traded sector choose the production plan $\widehat{k}_{0 t}, \widehat{\ell}_{0 t}$ to minimize costs and to earn zero profits:

$$
\begin{aligned}
\widehat{w}_{t} & \geq\left(1-\alpha_{0}\right) A_{0}\left(\widehat{k}_{0 t} / \widehat{\ell}_{0 t}\right)^{\alpha_{0}}, \quad=\text { if } \hat{\ell}_{0 t}>0 \\
1+\widehat{r}_{t} & \geq\left(\alpha_{0} A_{0}\left(\hat{\ell}_{0 t} / k_{0 t}\right)^{1-\alpha_{0}}+(1-\delta) \widehat{q}_{t}\right) / \widehat{q}_{t-1}, \quad=\text { if } \widehat{k}_{0 t}>0 \\
\widehat{\nu}_{0} & \geq \alpha_{0} A_{0}\left(\widehat{\ell}_{00} / \widehat{k}_{00}\right)^{1-\alpha_{0}}+(1-\delta) \widehat{q}_{0}, \quad=\text { if } \widehat{k}_{00}>0 .
\end{aligned}
$$

3. Given the prices $\widehat{p}_{t}, \widehat{w}_{t}, \widehat{r}_{t}, \widehat{q}_{t}, \widehat{\nu}_{0}$ producers in the nontraded sector choose the production plan $\widehat{k}_{1 t}, \widehat{\ell}_{1 t}$ to minimize costs and to earn zero profits:

$$
\begin{aligned}
\widehat{w}_{t} & =\widehat{p}_{t}\left(1-\alpha_{1}\right) A_{1}\left(\widehat{k}_{1 t} / \widehat{\ell}_{1 t}\right)^{\alpha_{1}} \\
1+\widehat{r}_{t} & =\left(\widehat{p}_{t} \alpha_{1} A_{1}\left(\widehat{\ell}_{1 t} / \widehat{k}_{1 t}\right)^{1-\alpha_{1}}+(1-\delta) \widehat{q}_{t}\right) / \widehat{q}_{t-1} \\
\widehat{\nu}_{0} & =\widehat{p}_{0} \alpha_{1} A_{1}\left(\widehat{\ell}_{10} / \widehat{k}_{10}\right)^{1-\alpha_{1}}+(1-\delta) \widehat{q}_{0} .
\end{aligned}
$$


4. Given the prices $\widehat{p}_{t}, \widehat{q}_{t}$, producers in the investment sector choose inputs $\widehat{z}_{0 t}, \widehat{z}_{1 t}$ to minimize costs and to earn zero profits:

$$
\begin{aligned}
1 \geq \widehat{q}_{t} \gamma G\left(\widehat{z}_{1 t} / \widehat{z}_{0 t}\right)^{1-\gamma}, & = & \text { if } \widehat{z}_{0 t}>0 \\
\widehat{p}_{t} \geq \widehat{q}_{t}(1-\gamma) G\left(\widehat{z}_{0 t} / \widehat{z}_{1 t}\right)^{\gamma}, & = & \text { if } \widehat{z}_{1 t}>0 .
\end{aligned}
$$

5. The market clearing conditions in goods markets in (14) and (15) hold. If the economy is closed in period $t, \widehat{b}_{t+1}=0$. If the economy is open in period $t, \widehat{r}_{t+1}=r^{*}$.

6. The market clearing conditions in the asset market (13) and the investment market (16) hold.

7. The market clearing conditions in the factor markets hold:

$$
\begin{aligned}
\widehat{k}_{0 t}+\widehat{k}_{1 t} & \leq \widehat{k}_{t} \\
\widehat{\ell}_{0 t}+\widehat{\ell}_{1 t} & \leq \bar{\ell} .
\end{aligned}
$$

Notice that we allow the possibility of no production in the traded sector and the investment sector in our definition of equilibrium. In the case that we are interested in, where a relatively capital poor country opens itself, it is only the possibility of no production in the trade sector that is of interest: imports of the traded good can be so large that the economy specializes for some periods in producing the nontraded good and the investment good.

The profit maximization conditions for capital in the traded sector (18) and the nontraded sector (21) can easily reinterpreted as no-arbitrage conditions: Purchasing one unit of the investment good in period $t-1$ costs $\widehat{q}_{t-1}$ and yields $\alpha_{0} A_{0}\left(\widehat{\ell}_{0 t} / \widehat{k}_{0 t}\right)^{1-\alpha_{0}}+(1-\delta) \widehat{q}_{t}$ if that investment good is employed as capital in the traded sector. The rate of return on this investment must equal that on purchasing a bond, $\widehat{r}_{t}$.

It may also be helpful to notice that we could have defined a price of capital before production takes place in every period $t, \widehat{\nu}_{t}$, not just in period 0 . In this case, the no-arbitrage condition would have been

$$
\left(1+\widehat{r}_{t}\right) \widehat{q}_{t-1}=\widehat{\nu}_{t}
$$

which says that investing $\widehat{q}_{t-1}$ in period $t-1$ must yield $\left(1+\widehat{r}_{t}\right) \widehat{q}_{t-1}$ whether the investment is in physical capital or in bonds. To conserve on notation, we have left this relationship implicit in our definition of equilibrium.

\section{Calibration}

In calibrating the model presented in the previous section we have two objectives: First, we want to match certain key data in the Spanish national income and product accounts and the Spanish input-output matrix for 1986. Second, we want to be consistent with the calculations in section 2 about the extent to which differences in output per worker between Spain and Germany can be explained by differences in capital per worker.

In the appendix we explain how we have constructed an aggregated input-output matrix for the Spanish economy in 1986 under the assumption that Spain was closed to capital flows at the time. We normalize all prices except the rental rate of capital to be 1 in 1986 and all quantities except the capital stock to be equal to their monetary values in the 1986 input-output matrix. We rely on 
the Summers-Heston (1991) data to calculate the 1986 capital stock. Payments to capital divided by the capital stock then give us the rental rate of capital.

We begin by calibrating the production functions for the traded sector and the nontraded sector. Normalizing GDP to be 100 in 1986, the Spanish input-output matrix says that GDP by sector is $y_{0}=37.1433$ and $y_{1}=62.8567$. The input-output matrix also suggests that the capital shares are $\alpha_{0}=0.5402$ and $\alpha_{1}=0.5854$. (We have excluded services not for sale from the calculation of $\alpha_{1}$ because of the lack of consistent accounting for capital inputs in these sectors.) This would imply an aggregate capital share of

$$
\alpha=\left(\alpha_{0} y_{0}+\alpha_{1} y_{1}\right) / y=0.5686
$$

where $y=y_{0}+y_{1}$ is total output. This number is too high, however, because of the convention of including the income of self-employed and family workers (which is large in Spain) in capital income. If we make an adjustment for this income as done by the Commission of the European Communities (1994), we obtain $\alpha=0.3020$. Because of lack of information to make this adjustment separately by sectors, we do it proportionally, obtaining $\alpha_{0}=0.2869$ and $\alpha_{1}=0.3109$.

We can normalize labor units by their values in 1986 ,

$$
\ell_{j}=\left(1-\alpha_{j}\right) y_{j}, \quad j=0,1
$$

obtaining $\ell_{0}=26.4864$ and $\ell_{1}=43.3136$; aggregate labor is $\bar{\ell}=69.8000$. We want our measures of capital in each sector to be consistent with the capital output ratio $k / y=2.0711$ in the SummersHeston (1991) data set:

$$
k_{j}=\left(\alpha_{j} / \alpha\right) y_{j}(k / y), \quad j=0,1 .
$$

We obtain $k_{0}=73.0806$ and $k_{1}=134.0280$; aggregate capital is $k=207.1086$.

Calibrating the constants $A_{0}$ and $A_{1}$ to obtain the desired outputs given the inputs, we obtain

$$
\begin{aligned}
& y_{0}=1.0481 k_{0}^{0.2869} \ell_{0}^{0.7131} \\
& y_{1}=1.0214 k_{1}^{0.3109} \ell_{1}^{0.6891} .
\end{aligned}
$$

We now calibrate the production function for the investment sector. Keeping our normalization of $y=100$, the national income accounts say that total investment is $x=20.1875$. According to the input-output matrix, the inputs into investment by sector are $z_{0}=7.6762$ and $z_{1}=12.5113$. This allows us to calibrate

$$
x=1.9434 z_{0}^{0.3802} z_{1}^{0.6198} .
$$

Let us define periods in the model as being one year. According to the national income accounts, depreciation is $\delta k=11.9350$. Dividing through by our estimate of $k$, we calibrate $\delta=0.0576$.

To calibrate the parameters of the utility function, we can calculate consumption by sector residually:

$$
c_{i}=y_{i}-z_{i}, \quad i=0,1 .
$$

(In our model, $c_{i}$ is conceptually private consumption plus government consumption; because of treatment of Spain as closed in 1986 , in practice, $c_{i}$ excludes net exports.) We obtain $c_{0}=29.4671$ and $c_{1}=50.3454$. Using the first order conditions from the consumer's problem, we obtain

$$
\epsilon=\frac{\left(c_{0} / c_{1}\right)^{1-\rho}}{1+\left(c_{0} / c_{1}\right)^{1-\rho}}=\frac{0.5830^{1-\rho}}{1+0.5830^{1-\rho}} .
$$


In our simulations, we use a value of $\rho=-1$, which implies an intertemporal elasticity of substitution of $1 /(1-\rho)=0.5$ and is fairly standard (see, for example, Mankiw, Rotemberg, and Summers, 1985).

The only remaining parameter to be calibrated is $\beta$. As in section 2 , we assume that Germany is in a steady state and that Germany has the same, $\alpha, \beta$, and $\delta$ as Spain. In this steady state, we know that

$$
1+\alpha A_{\text {ger }} k_{\text {ger }}^{\alpha-1}-\delta=1 / \beta .
$$

(Here, of course, $k_{\text {ger }}$ is the German capital per worker used in section 2.) This implies that $\beta=0.9463$.

In specifying and calibrating the model, we have ignored technological progress. It is fairly easy to show, however, that with minor modifications the model can be transformed into one with the same constant rate of total factor productivity growth in the traded sector and the nontraded sector. The idea would be to put everything in terms of units per effective labor. We would need to modify those equations of the model where both period tand period $t+1$ variables occurthe budget constraint (12) which serves as a law of motion for total assets; the market clearing condition for the traded sector (15), which serves as a law of motion for foreign assets; and the market clearing condition for the investment sector (16), which serves as a law of motion for the capital stock - multiplying the period $t+1$ variables by the growth factor. We would also need to change slightly the calibration of the discount factor $\beta$. We do not carry out this transformation for two sets of reasons: First these changes do not have a significant effect on either the qualitative or the quantitative features of our results, but would greatly complicate the exposition. Second, as we stress later, more interesting modifications of the model would be to allow different rates of growth of technical progress, either between Spain and Germany or between the traded sector and the nontraded sector.

\section{Simulation of the Basic Model}

In this section we simulate the model presented and calibrated in the previous two sections. We assume that the economy is closed in the first and second period (1985 and 1986), but in the third period (1987), after the financial reforms that accompanied Spain's entry into the European community take effect, the economy is open. It is worth commenting on the interactions that two simplifying assumptions in the specification of the model have with the simulation results: First, since there is only one traded good, a country closed to international capital flows is also closed to trade. Generalizing the analysis to allow more than one trade good would be interesting because it would allow us to model Spain, not as closed in 1985, but as reducing its trade barriers. As we have explained, it would also allow us to account for changes in the relative prices of traded goods, which could help to explain some of the 74 percent of real exchange rate fluctuations not accounted for by changes in the relative prices of nontraded goods. Second, not allowing for differences in productivity growth between Spain and Germany, we are assuming that all changes in relative incomes after the financial reforms are due to capital flows. We could also imagine an alternative model in which the productivity parameters $A_{j}$ are endogenous, depending on factors like human capital accumulation and learning by doing. Even so, our analysis, which fixes productivity differences between Spain and Germany, is still valid to the extent to which capital flows occur faster than the endogenous growth process changes total factor productivity.

Figures 3 and 4 present the results of the simulation. Figure 3 compares the behavior of the trade balance, as a percent of GDP, in the model with that in the data. Figure 4 compares the real 
exchange rate in the model with the explained real exchange rate in figure 2.

Notice that the presence of the nontraded sector does cause the results to differ from that of a one sector model. All of the capital inflows do not take place in the first period, and the adjustment to the steady state is not immediate. (One reason for this is that in the third period, 1987, the Spanish economy specializes and produces no traded goods.) The real exchange rate also moves in the right direction qualitatively, first appreciating with the capital inflows and then depreciating. Nonetheless, although the direction of change of the variables is right, the magnitudes and the timing are wrong. In the model the trade deficit reaches a peak of 59.91 percent of GDP in 1987, while in the data the trade deficit reaches a peak of 3.38 percent of GDP in 1990. In the model the appreciation of the real exchange rate reaches a peak of 0.64 percent in 1987, while in the data the appreciation of the real exchange rate reaches a peak of 9.42 percent in 1991. (Notice that the real exchange rate series reported is what is called the explained real exchange rate in section 2.) Overall, capital flows are far too large and fast, and the real exchange rate fluctuations are far too small.

\section{The Production Possibility Frontier Revisited}

The exercise in the previous section fails quantitatively because the production possibility frontier is too flat. Observe how similar are the parameters that we have calibrated for the capital share in the traded sector, $\alpha_{0}=0.2869$, and that in the nontraded sector, $\alpha_{1}=0.3109$. If these two parameters were the same, the economy would behave like a one sector model (except for complications due to the possibility of complete specialization), with all of the capital inflows occurring in the first period and no change in the real exchange rate.

In the next section we investigate the extent to which frictions on the movements of factors from one sector to the other can put more curvature into the production possibility Frontier in figure 1. In this section we argued that, with complete factor mobility, no plausible changes in the production function for the traded good and the nontraded good can produce the sorts of changes observed in the relative price of the nontraded good without current account deficits much larger than those actually observed.

As Patrick Kehoe has pointed out to the authors, the matter is a simple quantitative question about production functions: At its peak, in 1990, the Spanish trade deficit reached 0.0338 of GDP, which was equivalent to 0.0910 of base year production of the traded good. This tells us the observed shift along the production possibility frontier. The extent to which we can account for this change in quantities depends, of course, on the specification of consumption and investment behavior - on the elasticity of substitution between traded and nontraded goods in investment (33), for example. Supposing that we can account for this change in quantities, however, the question of whether or not we can account for the change in relative prices is a question only about the curvature of the production possibility frontier, which depends only on the production functions.

Let us generalize the production functions in (14) and (15) to allow a constant elasticity of substitution:

$$
y_{j}=A_{j}\left[\alpha_{j} k_{j}^{\nu}+\left(1-\alpha_{j}\right) \ell_{j}^{\nu}\right]^{1 / \nu}, \quad j=0,1,
$$

where $1 /(1-\nu)$ is the elasticity of substitution between capital and labor, and the Cobb-Douglas functions that we have used are the limiting case where $\nu=0$. The feasibility conditions for factors remain the same as (25) and (26):

$$
k_{0}+k_{1}=k
$$




$$
\ell_{0}+\ell_{1}=\ell
$$

(It is here, of course, that we are assuming complete factor mobility.) The marginal product pricing conditions on capital, equations (18) and (21) become

$$
r^{k}=\alpha_{0}\left(y_{0} / k_{0}\right)^{1-\nu}=p \alpha_{1}\left(y_{1} / k_{1}\right)^{1-\nu}
$$

where $r^{k}$ is the rental rate on capital (not the real interest rate). Similarly, the marginal product pricing conditions on labor, equations (17) and (20), become

$$
w=\left(1-\alpha_{0}\right)\left(y_{0} / \ell_{0}\right)^{1-\nu}=p\left(1-\alpha_{1}\right)\left(y_{1} / \ell_{1}\right)^{1-\nu}
$$

which implies that

$$
p=\frac{1-\alpha_{0}}{1-\alpha_{1}}\left(\frac{y_{0} \ell_{1}}{y_{1} \ell_{0}}\right)^{1-\nu} .
$$

Combining equations (40) and (41) implies that

$$
\frac{\alpha_{0}}{1-\alpha_{0}}\left(\frac{\ell_{0}}{k_{0}}\right)^{1-\nu}=\frac{\alpha_{1}}{1-\alpha_{1}}\left(\frac{\ell_{1}}{k_{1}}\right)^{1-\nu}
$$

We want to obtain an expression that tells us how the relative price of the nontraded good $p$ changes as production of the traded good $y_{0}$ changes. To do so, we totally differentiate the system of equations (37)-(43). Letting $\widehat{y}_{0}$ now denote $d y_{0} / y_{0}$, for example, we want to find an expression for $\widehat{p}$ in terms of $\widehat{y}_{0}$, parameters, and 1986 values of the variables. (In using calculus methods to approximate the change in $p$, we are implicitly ruling out the sort of corner solution obtained in the previous section where the economy does not produce the traded good.)

Combining expressions using simple, but tedious, algebraic manipulation yields

$$
\widehat{p}=(1-\nu)\left[\frac{(1-\beta) \beta_{0} \beta_{1}+\beta\left(1-\beta_{0}\right)\left(1-\beta_{1}\right)-\beta(1-\beta)}{(1-\beta) \beta_{0} \beta_{1}+\beta\left(1-\beta_{0}\right)\left(1-\beta_{1}\right)}\right] \frac{y \widehat{y}_{0}}{y_{1}} .
$$

where

$$
\begin{aligned}
\beta_{j} & =r^{k} k_{j} / y_{j}=\alpha_{j}\left(k_{j} / y_{j}\right)^{\nu}, \quad j=0,1 \\
\beta & =\beta_{0} y_{0} / y+\beta_{1} y_{1} / y
\end{aligned}
$$

Here $\beta_{j}$ is the 1986 capital share in sector $j$, and $\beta$ is the aggregate 1986 capital share.

Let us now experiment with changing the share parameters $\beta_{0}$ and $\beta_{1}$ and the elasticity parameter $\nu$ to see what values we can obtain for $\widehat{p}$ In doing so, we maintain the observed aggregate capital share in $1986, \beta=0.3020$ by requiring that (46) holds, that

$$
0.3020=0.3714 \beta_{0}+0.6286 \beta_{1} .
$$

We also will fix $\widehat{y}_{0}=0.0910$, the observed maximum replacement of domestic production by imports.

What value of $\widehat{p}$ would we like to obtain? If we normalize all prices in 1986 to be 1 , our explained real exchange rate (10) becomes

$$
\left(y_{0}+y_{1}\right) /\left(y_{0}+p y_{1}\right)=(0.3714+0.6286 p)^{-1} .
$$


The explained real exchange rate fell to 0.9139 in 1992. To account for this appreciation, we would need $p=1.1499$; that is, $\widehat{p}=0.1499$.

Figure 5 graphs the percentage appreciation of the real exchange rate (48), which is $\widehat{p} y_{1}$, against $\beta_{0}$, with $\beta_{1}$ determined by (47), for different values of $\nu$. Notice that, although values of $\widehat{p} y_{1}$ as large as the observed $0.0942(=1 / 0.9139-1)$ are possible, they can be obtained only for values of $\beta_{0}$ far different from that we have calibrated to and values of $\nu$ far different from 0 . It should be noted that values of $\nu$ like -9 , which implies an elasticity of substitution of 0.1 , would lead to wild fluctuations in factor shares as relative prices change. In fact, however, the aggregate capital share in Spain, whether we use the data unadjusted for income of self-employed workers from the national accounts or the data adjusted for income of self-employed workers from Commission of the European Communities (1994), has been fairly constant since 1986.

There are other specifications of the production functions (37) that we could experiment with, such as allowing different sectors to have different elasticities of substitution. It does not seem plausible, however, that such specifications can at the same time be consistent with the observed changes in prices and quantities and not wildly inconsistent with other observations.

\section{$7 \quad$ Frictions in Factor Mobility}

In this section we experiment with different ways of imposing frictions on the mobility of factors of production between the traded sector and the nontraded sector. Such frictions can slow down capital inflows. By providing more curvature to the production possibility frontier in the short run in figure 1, such frictions can also make relative prices more responsive to quantity movements. All of the different ways of imposing frictions that we study have the desired effects on the behavior of the trade balance and the real exchange rate. To judge among them, we investigate the implications of different ways of modeling frictions for such other variables as output, employment, and relative wages by sector.

We begin specifying capital adjustment costs using the same constant-returns-to-scale technology as in Lucas and Prescott (1971). We replace the specification of the investment technology (16) with

$$
\begin{aligned}
x_{0 t+1}+x_{1 t+1} & \leq G z_{0 t}^{\gamma} z_{1 t}^{1-\gamma} \\
k_{0 t+1} & \leq \phi\left(x_{0 t+1} / k_{0 t}\right) k_{0 t}+(1-\delta) k_{0 t} \\
k_{1 t+1} & \leq \phi\left(x_{1 t+1} / k_{1 t}\right) k_{1 t}+(1-\delta) k_{1 t} .
\end{aligned}
$$

Here $\phi$ is a function with the properties $\phi^{\prime}(x / k)>0, \phi^{\prime \prime}(x / k) \leq 0, \phi(\delta)=\delta$, and $\phi^{\prime}(\delta)=1$. To make things simple, we use the simple, one parameter function

$$
\phi(x / k)=\left(\delta^{1-\eta}(x / k)^{\eta}-(1-\eta) \delta\right) / \eta \quad 0<\eta \leq 1
$$

Notice that the basic model corresponds to the case where $\eta=1$, and $\phi(x / k) k=x$.

Figures 6 and 7 present the results of the model with capital adjustment costs where $\eta=0.9$. In figure 6 notice that frictions in capital adjustment do indeed slow down capital inflows. In the model the trade deficit now reaches a peak of 9.36 percent of GDP in 1987, compared to the peak of 3.38 percent in 1990 in the data. In figure 7 notice that frictions in capital adjustment also make relative prices far more responsive. In the model the appreciation of the real exchange rate now reaches a peak of 5.46 percent in 1987, compared to the peak of 9.42 percent of 1991 in the data. 
We now experiment with imposing frictions on labor mobility. Perhaps the simplest way to do so is with restrictions that specify the maximum rate of growth of the labor force in a sector:

$$
\ell_{j+1} \leq \lambda \ell_{j t}, \quad j=0,1
$$

where $\lambda>1$. The basic model corresponds to the limiting case where $\lambda=\infty$. Of course, when this constraint binds, we need to allow the wage in sector $j$ to be higher than the wage in the other sector.

Figures 8 and 9 present the results of the model with limited labor mobility where $\lambda=1.01$. Once again capital flows slow down and real exchange rate movements increase: The trade deficit now reaches a peak of 5.71 percent of GDP in 1991, and real exchange rate appreciation reaches a peak of 9.05 percent in 1987 .

Figures 10 and 11 present the results of the model with both capital adjustment costs and limited labor mobility. The results for the trade balance and the real exchange rate are even better than those for the model with only limited labor mobility: The trade deficit reaches 4.87 percent of GDP in 1991 and real exchange rate appreciation reaches a peak of 9.28 percent in 1987.

Judging what specification of frictions in factor mobility has more potential to explain the Spanish experience is difficult on the basis of the results presented in figures 6-11 alone. The key parameters, $\eta=0.9$ in the case of capital adjustment costs and $\lambda=1.01$ in the case of restrictions on labor mobility, have been chosen more or less arbitrarily. Experimenting with lower values of $\eta$, for example, can lower the trade deficit in 1987. We therefore turn our attention to implications of the model for other observable variables.

Figures 12-14 present the results of different versions of the model for output by sector. Notice that, in figure12, the model with no frictions is a complete failure in this regard. It predicts that the percentage of GDP produced by traded sector should fall to 0 immediately after financial liberalization, with all traded goods being imported, and then rise sharply. In the data, the fraction of total output produced by the traded sector falls gradually over the period 1986-1993 and then flattens out. Notice too that, in figure 13, the model with capital adjustment costs also produces disappointing results, with a sharp initial fall in output of the traded sector followed by rapid increases. The results for the model with labor adjustment frictions for both capital and labor, presented in figure 14, look better: output of the traded sector falls gradually over the period 19861991 and then rises slowly. (Not surprisingly, the results for the model with only labor adjustment frictions, not shown here, fall between those in figure 13 and those in figure 14.)

It is worth stressing that different adjustment frictions have different implications for sectoral variables that need to be compared to the data. In the models with adjustment frictions on labor, for example, wage rates can differ across sectors, while in the models with no adjustment frictions or adjustment frictions only on capital wages are always equal across sectors. Figure 15 compares the results for relative wages between the traded sector and the nontraded sector in the model with adjustment frictions on both capital and labor with the data. Notice that the model predicts that wages in the traded sector should first fall relative to those in the nontraded sector and then rise. In the data, the decline in relative wages in the traded sector starts a year later and is not as steep: 2.75 percent in the data as opposed to 14.59 percent in the model. Although frictions in labor mobility are obviously an attractive candidate for making the model results match the data more closely, figure 15 indicates that more is still needed in modeling these frictions.

To appreciate the results produced by the different versions of the model it is useful to imagine how factors that have been left out of the analysis could affect the results. One obvious failing of all of the versions of the model is that they predict that the peak of real exchange rate appreciations 
should be in 1987. As Bacchetta (1991) points out, however, financial liberalization in Spain has been a gradual process. We could model this process by putting a wedge $\omega_{t}$ between the interest rate in the rest of the world, $r^{*}$, and that in Spain, $r^{*}+\omega_{t}$, and letting $\omega_{t}$ fall gradually. Such a modification of the model would shift real exchange rate appreciation into later years in all versions of the model. It would also shift the decline in the relative wage of the traded sector into later years for the two versions of the model with labor adjustment frictions.

Another obvious failing of all of the versions of the model is that they fail to take into account the obvious secular trends in output and labor utilization present in the data. In common with other countries of its level of development, Spain has been shifting production steadily out of agricultural and industry and into services. To account for this phenomenon we could provide the representative consumer with nonhomothetic preferences as in Echevarria (1995, 1997). Data also show that the percentage of labor utilization in the traded sector falls much faster than does the percentage of output produced by the traded sector in figures 12-14. One obvious explanation for this is that total factor productivity increased faster in the traded sector than in the nontraded sector along the lines suggested by the Balassa-Samuelson model (see, for example, Asea and Cordon, 1994). Incorporating these sorts of trends into the model would have the effect of tilting all of the model results in figures 12-14 downwards, making the results for the model with both capital and labor adjustment frictions (figure 14) look better. As a final adjustment to the model, we could give the Spanish economy in 1985 an initial negative stock of net foreign assets by specifying the initial assets the consumer's problem (12) as $a_{0}=\nu_{0} k_{0}+b_{0}$ and $b_{0}<0$. Such a modification would shift up all of the trade balances produced by the models since Spain would have to export more to service its increased debt. Notice, that, if we were to choose $b_{0}$ so that the trade deficit for the model with frictions on both capital and labor mobility in figure 10 were to shift up by about 2 percent, these figures would match the data very well.

\section{Concluding Remarks}

The results of the experiments reported in this paper have at least two important lessons: First, it is crucial to model frictions in factor mobility to obtain the observed relation between quantity movements and price movements. Second, incorporating such frictions into the model has implications for observable variables that need to be compared with the data.

The experiments with the model with frictions on both labor and capital movements have been particularly successful. As the discussion at the end of the previous section makes clear, it is possible to modify the model in such away as to obtain very close matches with the data. It is probably not worth doing so for at least two related reasons: First, there is only a limited amount to be learned from a case study such as this. There were other things going on in Spain over the period 1986-1996 besides financial liberalization, and there are sharply diminishing returns from trying to match every twist and turn in the data. Second, as our discussion in section 2 points out, our model cannot hope to account for the 74 percent of real exchange rate fluctuations due to changes in the relative prices of traded goods between countries. Rather than trying to match the data with the sorts of modifications of the current model suggested in the previous section, it would be worthwhile to build a model with a distinction between traded goods that are produced domestically and those that are imported. In such a model, where the terms of trade could fluctuate, we could hope to explain more of real exchange rate movements. It is intriguing, for example, to think about a model where increased foreign competition spurs productivity growth in the traded sector along the lines of Holmes and Schmitz (1995). After all, 1986 also marked the beginning of 
a significant commercial policy liberalization in Spain.

It is worth concluding with comparisons of two predictions of the model with the data:

First, on a positive note, as section 2 points out, the model predicts that, by building up its capital stock, Spain should be able to rapidly close its gap in output per worker with Germany to move from 78 percent of German GDP per worker to 92 percent. In fact, over the period 19861990 (the latest date for which data is available from the Summers, Eston, Aten, and Nuxoll, 1995 diskette), most of this gap closed: Spanish GDP per worker increased to 89 percent of German GDP per worker.

Second, on a negative note, the model fails spectacularly in explaining real interest rate differentials between Spain and Germany. It predicts that real interest rates should be constant at 5.7 percent in Germany, while in Spain they should start at 8.8 percent when the economy is closed and then fall to 5.7 percent after financial liberalization. In fact, however, the average real interest rate in Spain over the period 1980-1986 was lower than that in Germany (see appendix). After financial liberalization, real interest rates in Spain increased to the level of those in Germany. It may be possible to explain these anomalies in a model with credit rationing or other distortions in the credit market in Spain. We leave this as a topic for future research.

\section{Appendix:}

Real exchange rate data. The information on the Spanish GDP deflator, $P_{\text {esp }}$, in the formula for the real exchange rate (7), is taken from Ministerio de Economía y Hacienda (1997). The information on the German GDP deflator, $P_{\text {ger }}$, is taken from the Organization for Economic Cooperation and Development $(1994,1997)$. The nominal exchange rate data, NER, is derived from the end-of-period nominal exchange rates versus the U.S. dollar provided by the International Monetary Fund (1990, 1997).

The traded goods deflator for Spain, $P_{\mathrm{esp}}^{T}$, in the formula for the explained real exchange rate (10) is taken from Instituto Nacional de Estadídistica (1995, 1997). The corresponding deflator for Germany, $P_{\text {ger }}^{T}$, is taken from the Organization for Economic Cooperation and Development (1994, 1997). The data for Spain is derived by adding GDP in current prices of agriculture to GDP in current prices of industry, then dividing the sum by the corresponding sum of constant price GDPs. This procedure is less than ideal in two ways: First, it would be better to use total output rather than GDP data in forming the price indices. Second, it would have been better to subtract electricity, gas, and water out of the traded category and to add in transportation services. Unfortunately, although the Instituto Nacional de Estadistica publishes the sort of data that we would like to use in current prices, they do not publish it in constant prices and have been unwilling to provide it to the authors. Although total output data with the desired desegregation is available for Germany, we use the same sort of GDP data, obtained from the Organisation for Economic Cooperation and Development $(1994,1997)$ to be consistent.

Input-output matrix. We aggregate the 57 sector input-output matrix published by the Instituto Nacional de Estadística (1991) to obtain the 3 sector matrix presented in Table 1. Notice that in this matrix, if we normalize total GDP, which is 31,995 trillion pesetas, to be100, then GDP in sector 1 , the traded sector is

$$
y_{0}=100(11,884 / 31,995)=37.1433 \text {. }
$$

The figure for $y_{1}$ is obtained analogously. Notice too that the capital share in sector 1 , obtained 
by ignoring indirect taxes and transfers, is

$$
\alpha_{0}=5,928 /(4,852+6,121)=0.5402 .
$$

The figure for $\alpha_{1}$ is obtained analogously. Finally, notice that the amount of traded goods used by the investment sector is

$$
z_{0}=100(2,456 / 31,995)=7.6762 .
$$

The figure for $z_{1}$ is obtained analogously.

The information on depreciation is obtained from Instituto Nacional de Estadística(1995):

$$
\delta k=100(3,858 / 32,324)=11.9350 .
$$

Notice that the information in the input-output table we could easily calibrate a model with intermediate goods in the production functions:

$$
y_{j t}=\max \left[z_{0 j t} / a_{0 j}, z_{1 j t} / a_{1 j}, A_{j} k_{j t}^{\alpha_{j}} \ell_{j t}^{1-\alpha_{j}}\right], \quad j=1,2
$$

where $z_{i j t}$ is the inputs from sector i into sector $j$ in period $t$. It is in this sort of model that the distinction between total output and value added is crucial.

Real interest rates. The data on real interest rates discussed in section 8 are derived from the following procedure: Nominal lending rates for both Spain and Germany are taken from the International Monetary Fund $(1990,1997)$. Real rates are then obtained by subtracting the realized inflation rate as measured by changes in the same GDP deflators as used in the calculation of the real exchange rate. Over the period 1980-1986, this measure of the real interest rate averaged 4.5 percent in Spain and 8.1 percent in Germany. Over the period 1987-1993 it averaged 8.5 percent in Spain and 8.1 percent in Germany. 


\section{References}

[1] Asea, P. K. and W. M. Corden, eds., 1994, "Thirty years of the Balassa-Samuelson model," Review of International Economics, Special issue.

[2] Ayuso, J. and J. L. Escrivá, 1998, "Trends in the monetary policy strategy in Spain," in: J. L. Malo de Molina, J. Viñals and F. Gutiérrez, eds., Monetary Policy and Inflation in Spain, St. Martins Press, New York, for the Banco de España, 131-158.

[3] Bacchetta, P., 1991, "Abolishing capital controls in Spain: A challenge for the nineties," Working Paper 91-1, Institut d'Anàlisi Econòmica, Universitat Autònoma de Barcelona.

[4] Betts, C. M. and T .J. Kehoe, 1999, "Tradability of goods and real exchange rate fluctuations,"Manuscript, University of Southern California.

[5] Commission of the European Communities, 1994, Statistical appendix, European Economy, $58,142$.

[6] Echevarria, C., 1995, "Agricultural development vs. industrialization: Effects of trade," Canadian Journal of Economics, 28, 631-647.

[7] Echevarria, C., 1997, "Changes in sectoral composition associated with economic growth," International Economic Review, 38, 431-452.

[8] Engel, C. and K. Kletzer, 1989, "Saving and investment in an open economy with non-traded good," International Economic Review, 30, 735-752.

[9] Harrison, J., 1995, The Spanish Economy: From the Civil War to the European Community, Cambridge University Press, Cambridge, U.K.

[10] Holmes, T. J. and J. A. Schmitz, 1995, "Resistance to technology and trade between area," Federal Reserve Bank of Minneapolis Quarterly Review, Winter, 2-17.

[11] Instituto Nacional de Estadística, 1991, Contabilidad Nacional de España, Base 1985: Serie Contable 1985-1989 y Tabla Input-Output 1986 (Instituto Nacional de Estadística, Madrid).

[12] Instituto Nacional de Estadística, 1995, Anuario Estadístico 1994 (Instituto de Estadística, Madrid).

[13] Instituto Nacional de Estadística , 1997, Anuario Estadístico 1996 (Instituto Nacional de Estadística, Madrid).

[14] International Monetary Fund, 1990, International Financial Statistics Yearbook (International Monetary Fund, Washington).

[15] International Monetary Fund, 1997, International Financial Statistics Yearbook (International Monetary Fund, Washington).

[16] Kehoe, T.J. 1995, "What happened to Mexico in 1994-1995?" in P. J. Kehoe and T. J. Kehoe, eds., Modeling North American Economic Integration, Kluwer Academic Publishers, Boston, 131-148. 
[17] Lucas, R. E., 1990, "Why doesn't capital flow from rich to poor countries?" American Economic Review, 80, 92-96.

[18] Lucas, R. E. and E. C. Prescott, 1971, "Investment under uncertainty," Econometrica, 39, 659-681.

[19] Mankiw, N. G., J. J. Rotemberg, and L. H. Summers, 1985, "Intertemporal substitution in macroeconomics," Quarterly Journal of Economics, 100, 225-251.

[20] Mendoza, E. G., 1995, "The terms of trade, the real exchange rate, and economic fluctuations", International Economic Review, 36(1), 101-137.

[21] Mendoza, E. G. and M. Uribe, 1996, "The syndrome of exchange-rate-based stabilizations and the uncertain duration of currency regs," International Finance Discussion Paper 548, Board of Governors of the Federal Reserve System.

[22] Ministerio de Economía y Hacienda, 1997, Síntesis Mensual de Indicadores Economícos. Computer diskette 28/8/1997 (Ministerio de Economía y Hacienda, Madrid).

[23] Organization for Economic Cooperation and Development, 1994, Economic Surveys: Germany. Paris: OECD.

[24] Organization for Economic Cooperation and Development, 1997, Economic Surveys: Germany. Paris: OECD.

[25] Rebelo, S., 1993, "Inflation in fixed exchange regimes: The recent Portuguese experience," in: F. Torres and F. Giavazzi, eds., Adjustment and Growth in the European Monetary Union, Cambridge University Press, Cambridge, U.K., 128-148.

[26] Rebelo, S. and C. Vegh, 1995, "Real effects of exchange-rate-based stabilization: An analysis of competing theories," in: B. S. Bernanke and J. J. Rotemberg, eds., NBER Macroeconomics Annual 1995, MIT Press, Cambridge, MA, 125-173.

[27] Salmon, K. 1995, The Modern Spanish Economy: Transformation and Integration into Europe, Second Edition, St. Martin's Press, London.

[28] Summers, R. and A. Heston, 1991, The Penn WorldTable (Mark 5): An expanded set of international compatisons, 1950-1988, Quarterly Journal of Economics, 106, 327-368.

[29] Summers, R., A., Heston, B. Aten, and D. Nuxoll, 1995, Penn World Table 5.6, Computer diskette, University of Pennsylvania.

[30] Turnovsky, S.J., 1997, International Dynamic Macroeconomics, MIT Press, Cambrige, MA. 
Table I

AGGREGATED INPUT-OUTPUT MATRIX FOR SPAIN 1986

(Billion Pesetas)

\section{EXPENDITURES}

\begin{tabular}{|c|c|c|c|c|c|c|c|c|c|c|}
\hline & & 1 & 2 & 3 & $1+2+3$ & $C+G$ & $I$ & $X$ & $\begin{array}{c}C+G \\
+I+K \\
\end{array}$ & Total \\
\hline & 1 & 11,947 & 4,815 & 744 & 17,506 & 8,386 & 2,456 & 3,723 & 14,565 & 32,071 \\
\hline $\mathrm{R}$ & 2 & 2,875 & 5,384 & 707 & 8,966 & 13,143 & 4,003 & 1,008 & 18,154 & 27,120 \\
\hline $\mathrm{E}$ & 3 & 0 & 0 & 0 & 0 & 5,099 & 0 & 0 & 5,099 & 5,099 \\
\hline $\mathrm{C}$ & $1+2+3$ & 14,822 & 10,199 & 1,451 & 26,472 & 26,828 & 6,459 & 4,731 & 37,818 & 64,290 \\
\hline $\mathrm{E}$ & $\omega \ell$ & 4,852 & 6,121 & 3,616 & 14,589 & & & & & 14,589 \\
\hline I & $r k$ & 5,928 & 8,664 & 325 & 14,917 & & & & & 14,917 \\
\hline $\mathrm{P}$ & $\mathrm{T}$ & 1,104 & 1,678 & -293 & 2,489 & & & & & 2,489 \\
\hline $\mathrm{T}$ & $\omega \ell+r k+T$ & 11,884 & 16,463 & 3,648 & 31,995 & & & & & 31,995 \\
\hline $\mathrm{S}$ & $M$ & 5,365 & 458 & 0 & 5,823 & & & & & 5,823 \\
\hline & Total & 32,071 & 27,120 & 5,099 & 64,290 & 26,628 & 6,459 & 4,731 & 37,818 & \\
\hline
\end{tabular}

Source: derived from Instituto Nacional de Estadística (1991).

1. Agriculture plus industry (sectors 1-36).

2. Concstruction plus services for sale (sectors 37-53).

3. Services not for sale (sectors 54-57).

$w \ell$. Remuneration of employees.

$r k$. Net indirect taxes and transfers including value added tax.

$T$. Net indirect taxes and transfers including value added tax.

$M$. Imports.

$C+G$. Private consumption plus government consumption.

I. Investment plus inventory accumulation.

$X$. Exports 
troded

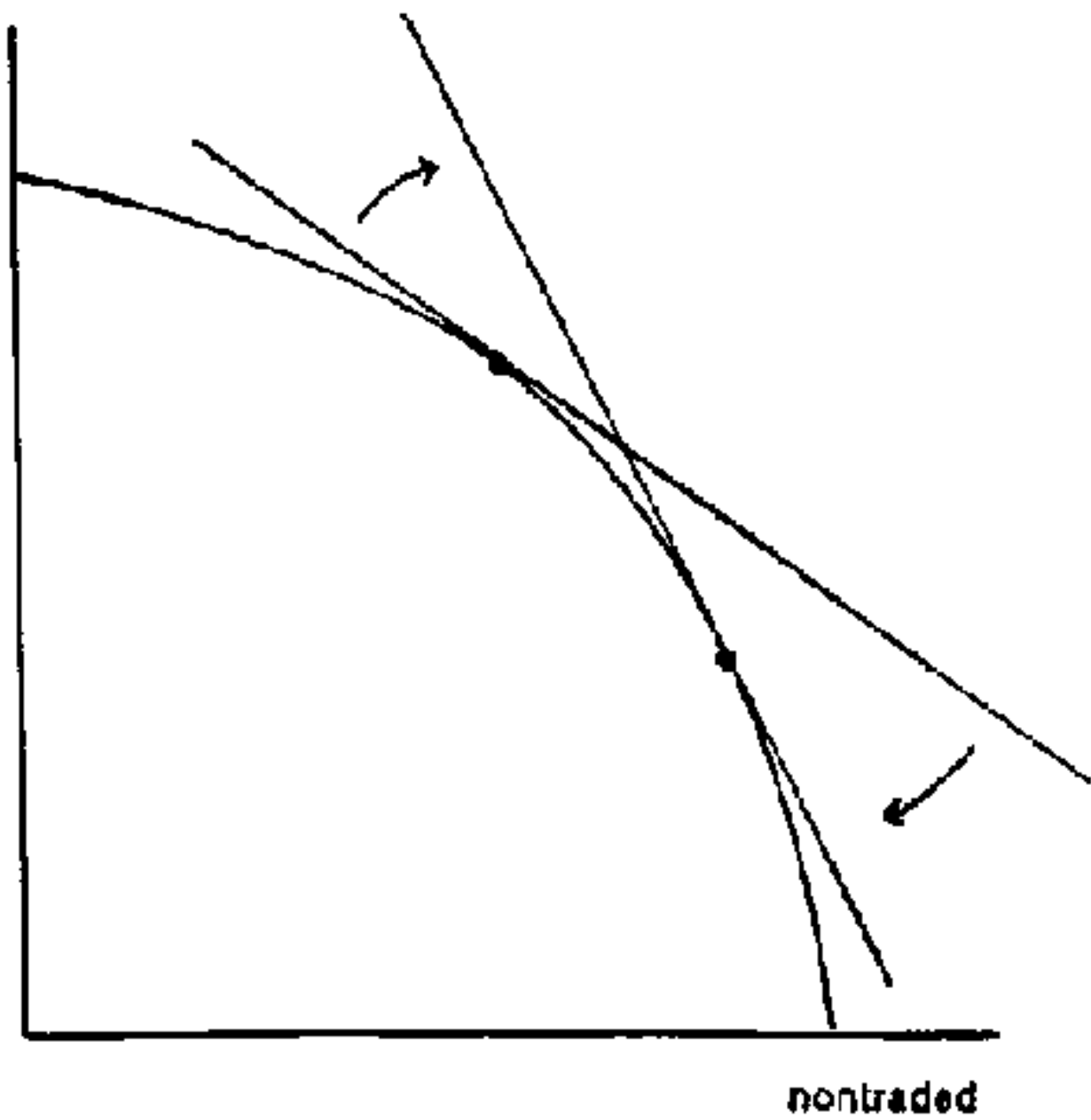

Figure 1: Change in relative prices of traded and nontraded goods 


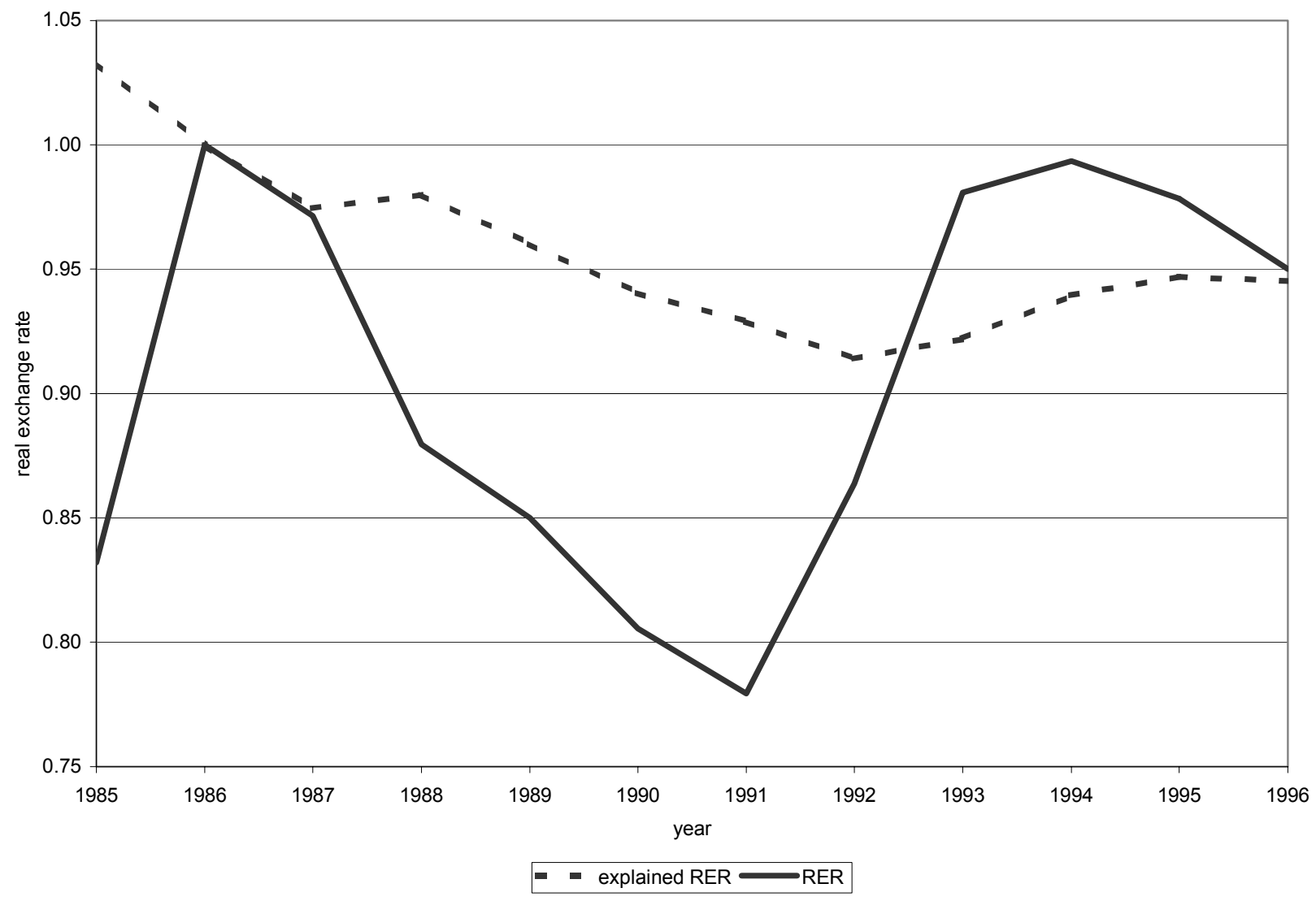

Figure 2: Peseta - Deutsche Mark real exchange rate 


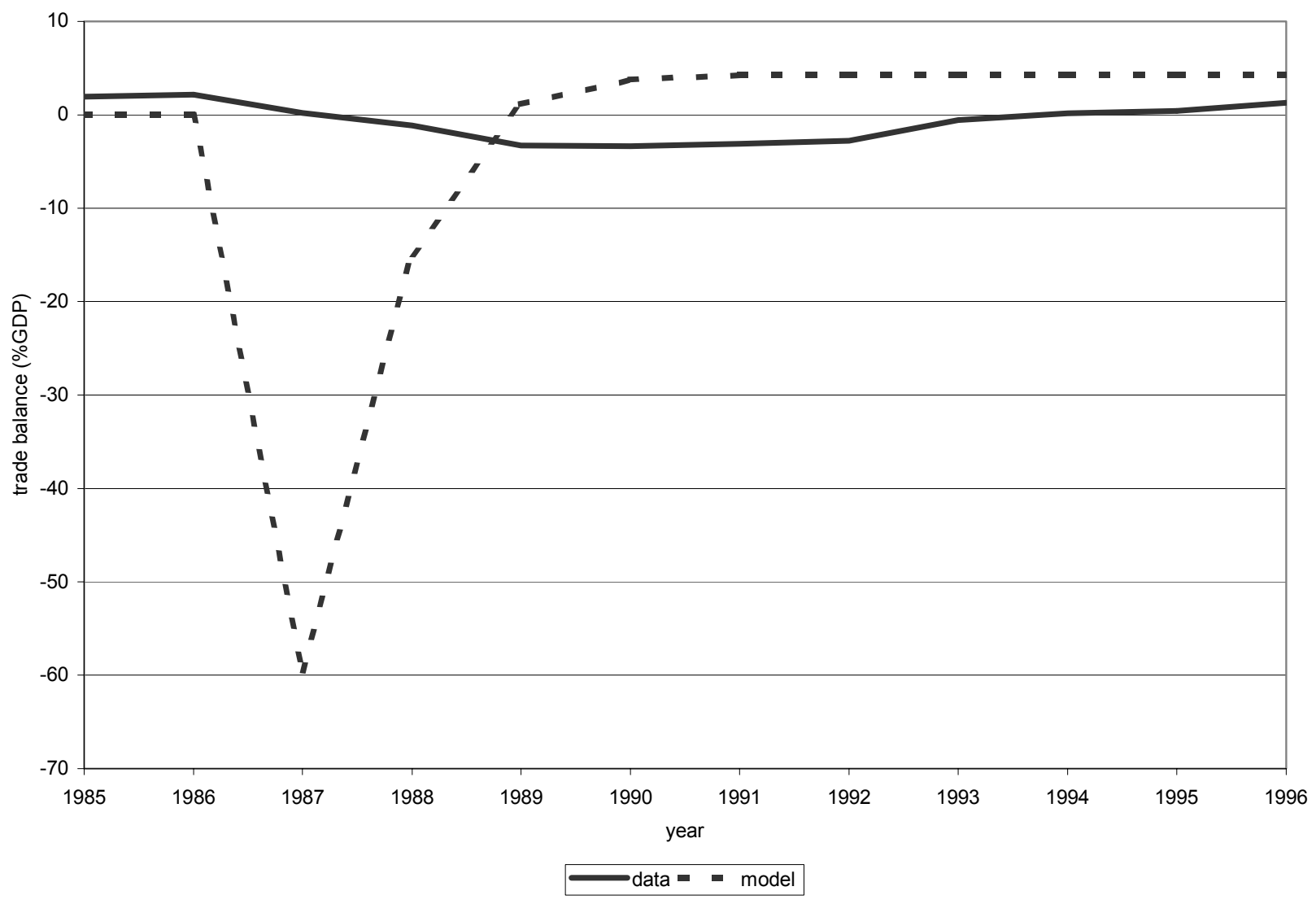

Figure 3: Basic model - trade balance. 


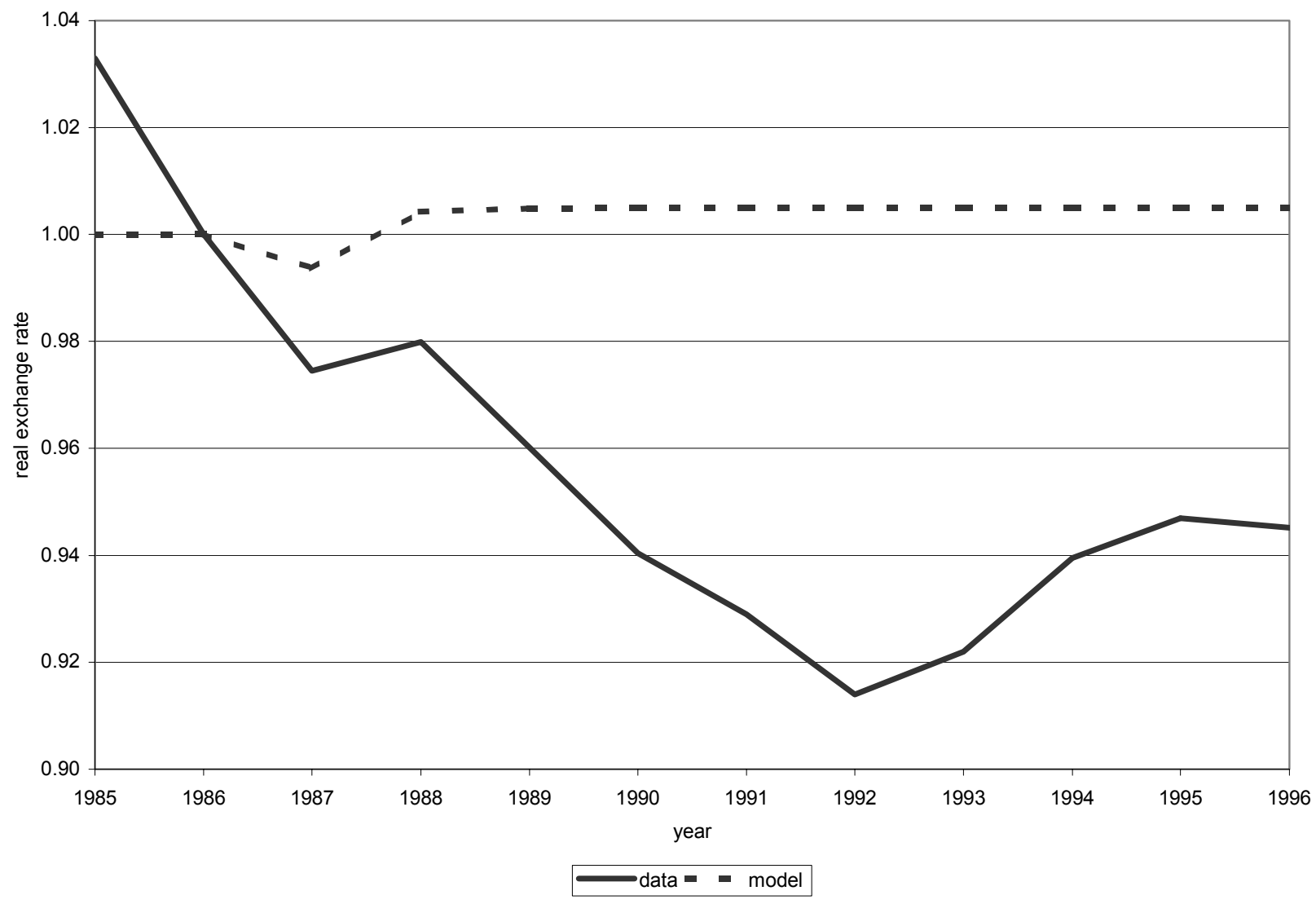

Figure 4: Basic model - real exchange rate. 


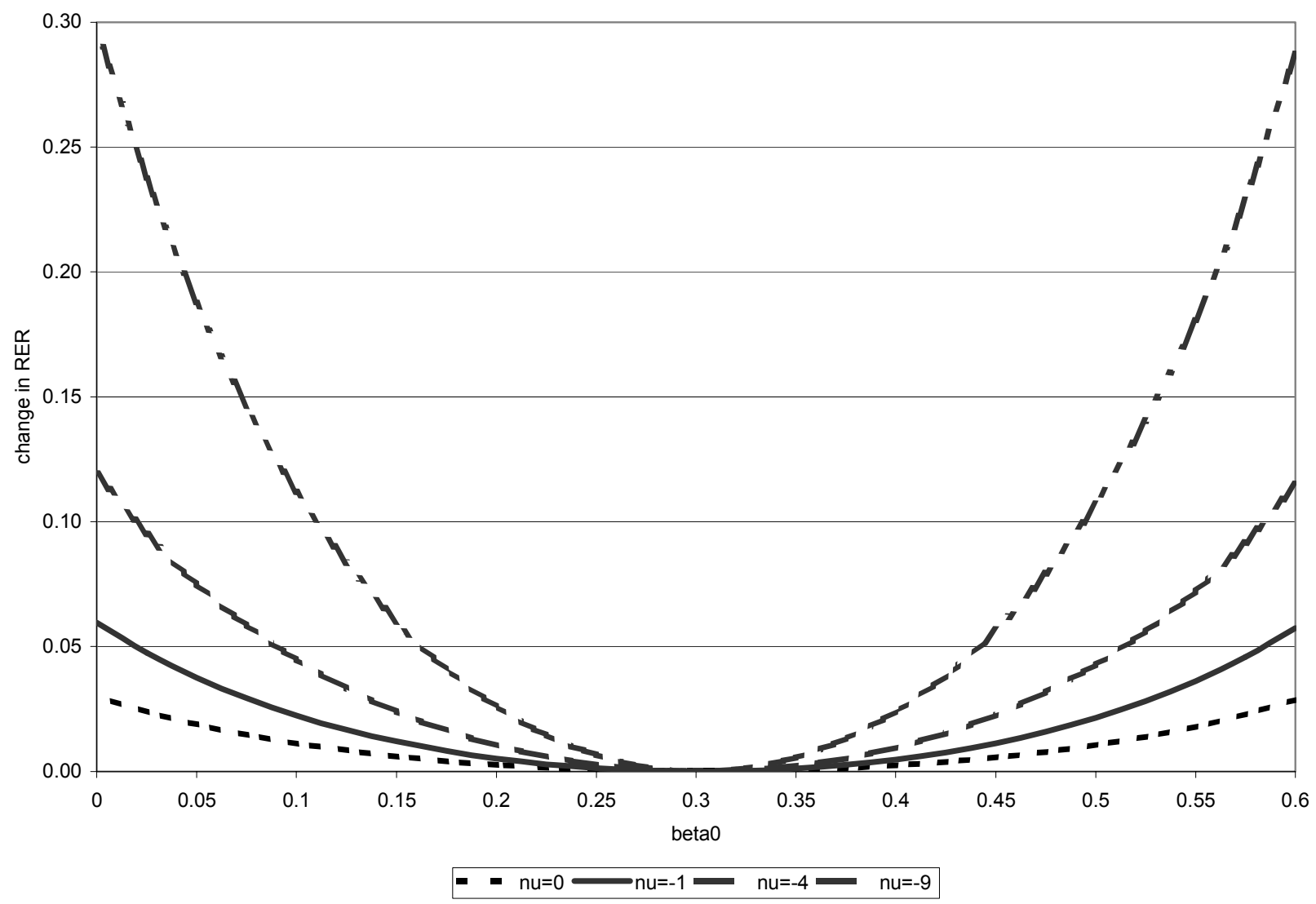

Figure 5: Chages in real exchange rate versus traded capital share 


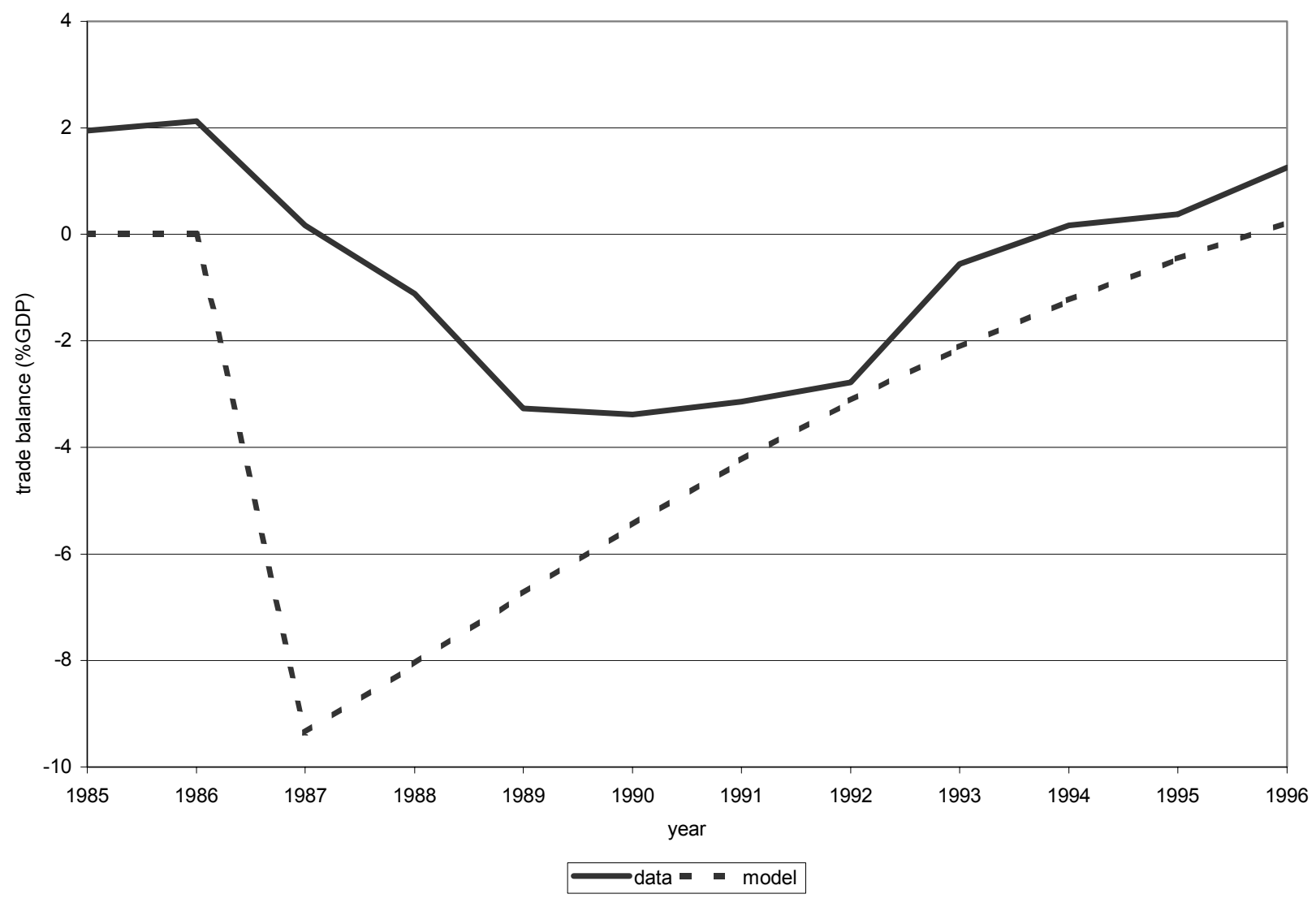

Figure 6: Model with capital adjustment frictions - trade balance. 


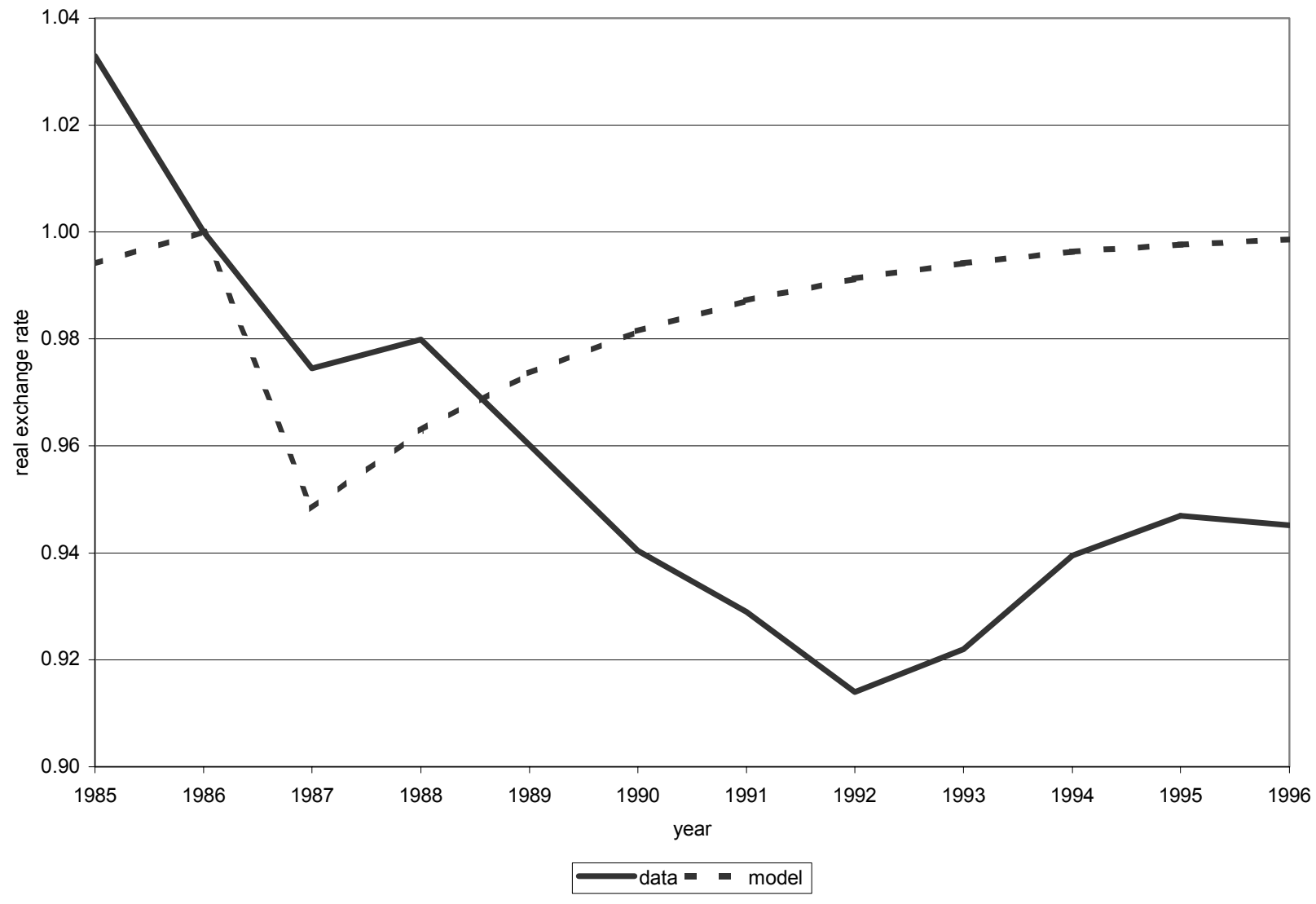

Figure 7: Model with capital adjustment friction - real exchange rate. 


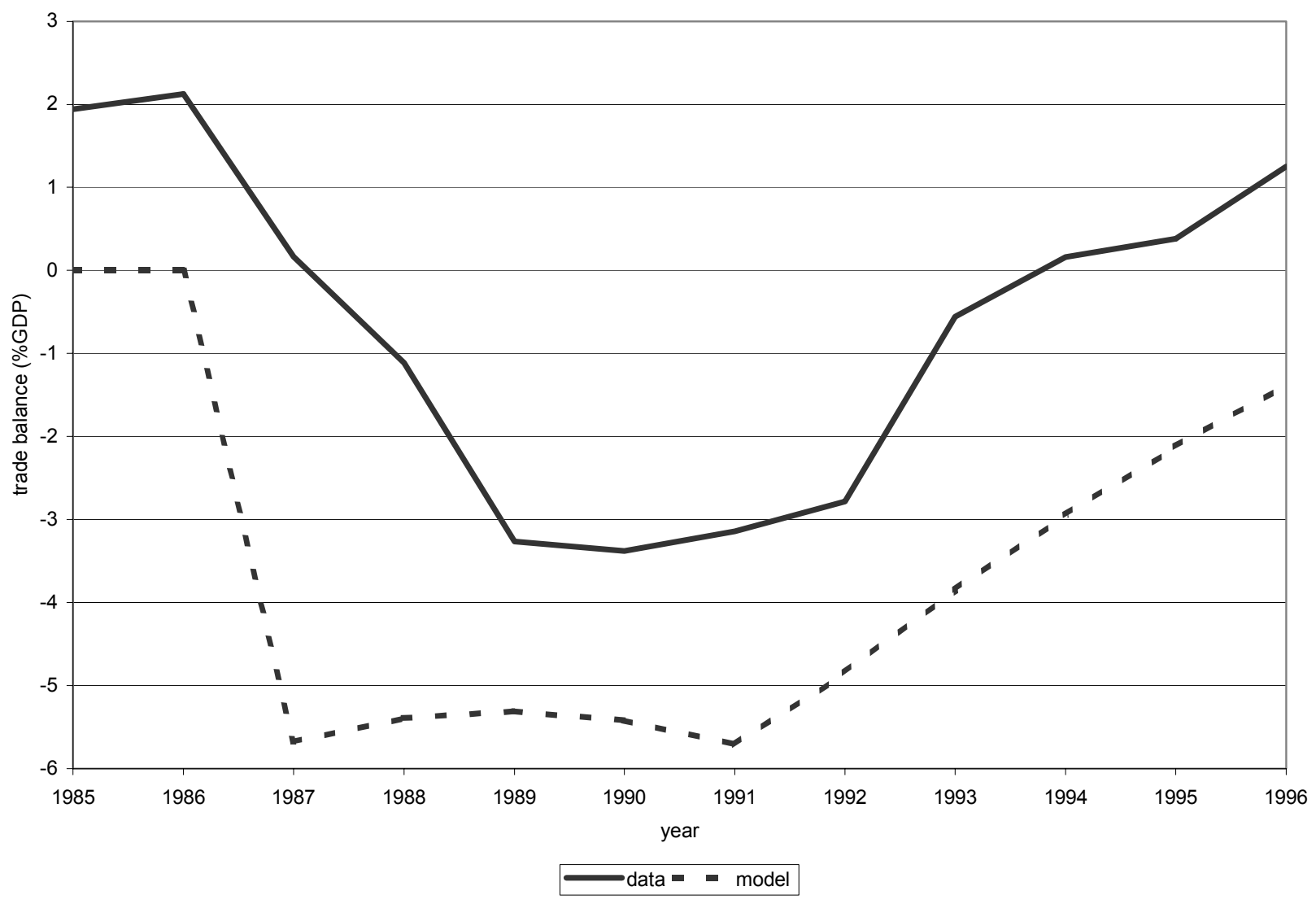

Figure 8: Model with labor adjustment frictions - trade balance. 


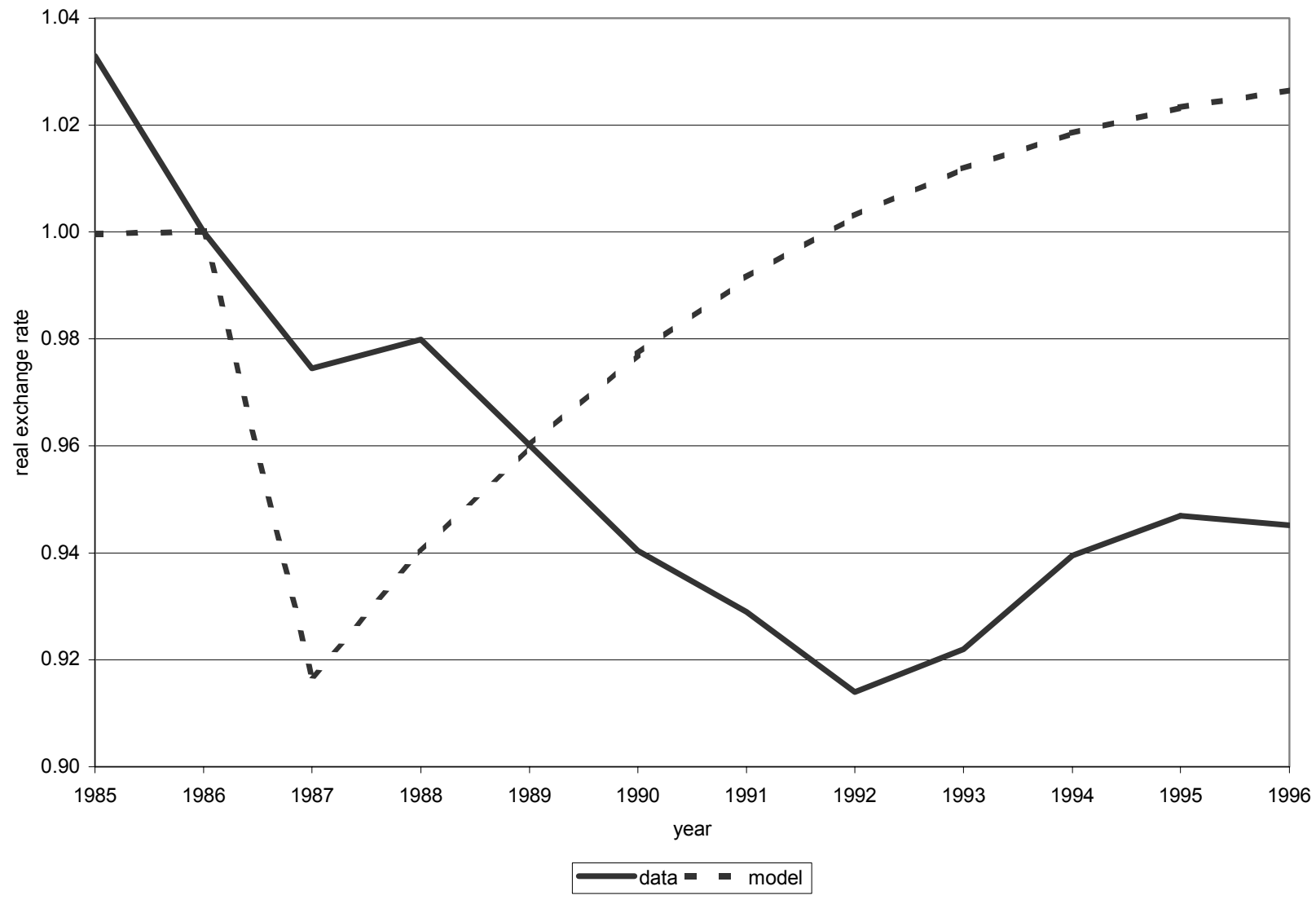

Figure 9: Model with labor adjustment frictions - real exchange rate. 


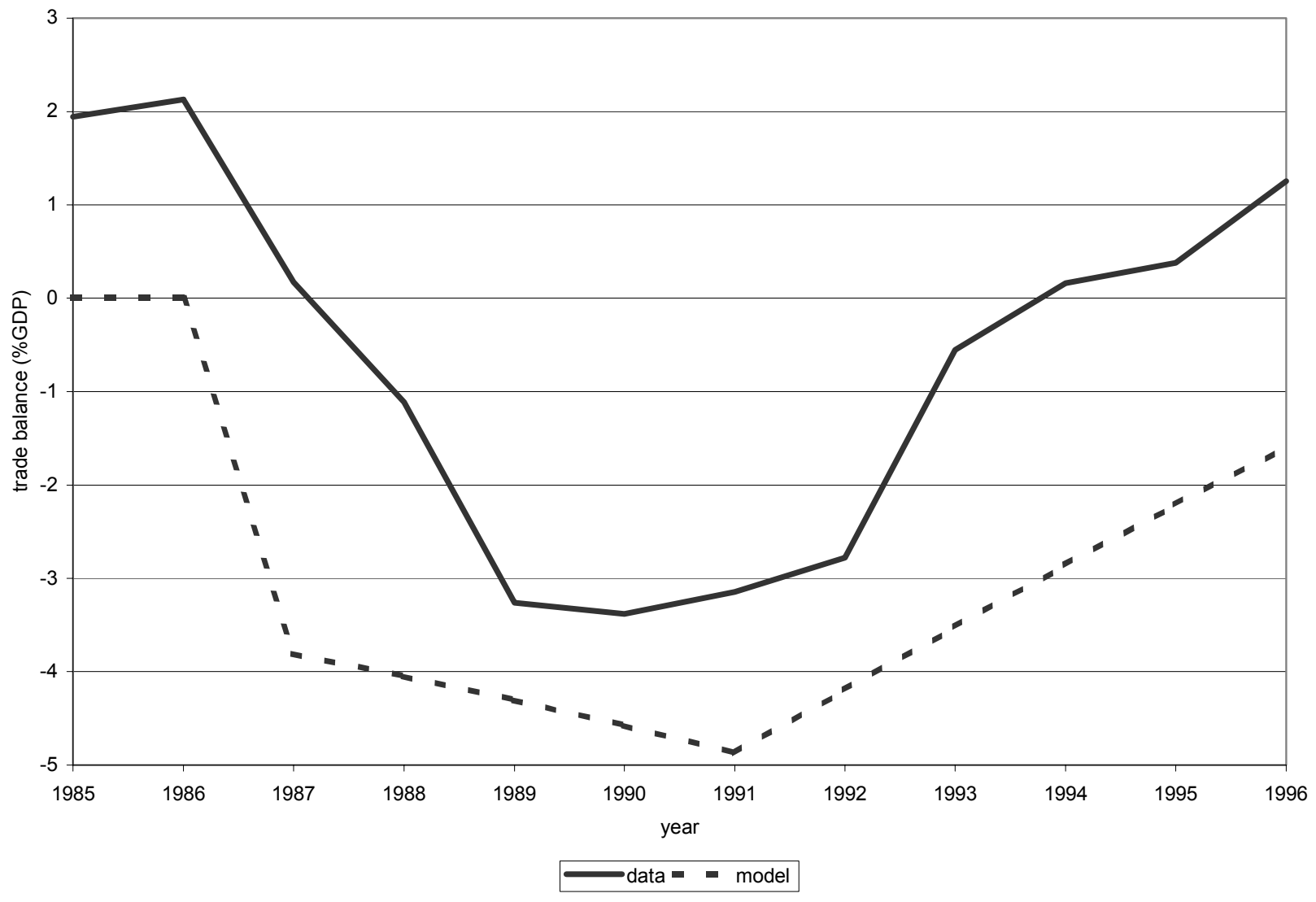

Figure 10: Model with capital and labor adjustment frictions - trade balance. 


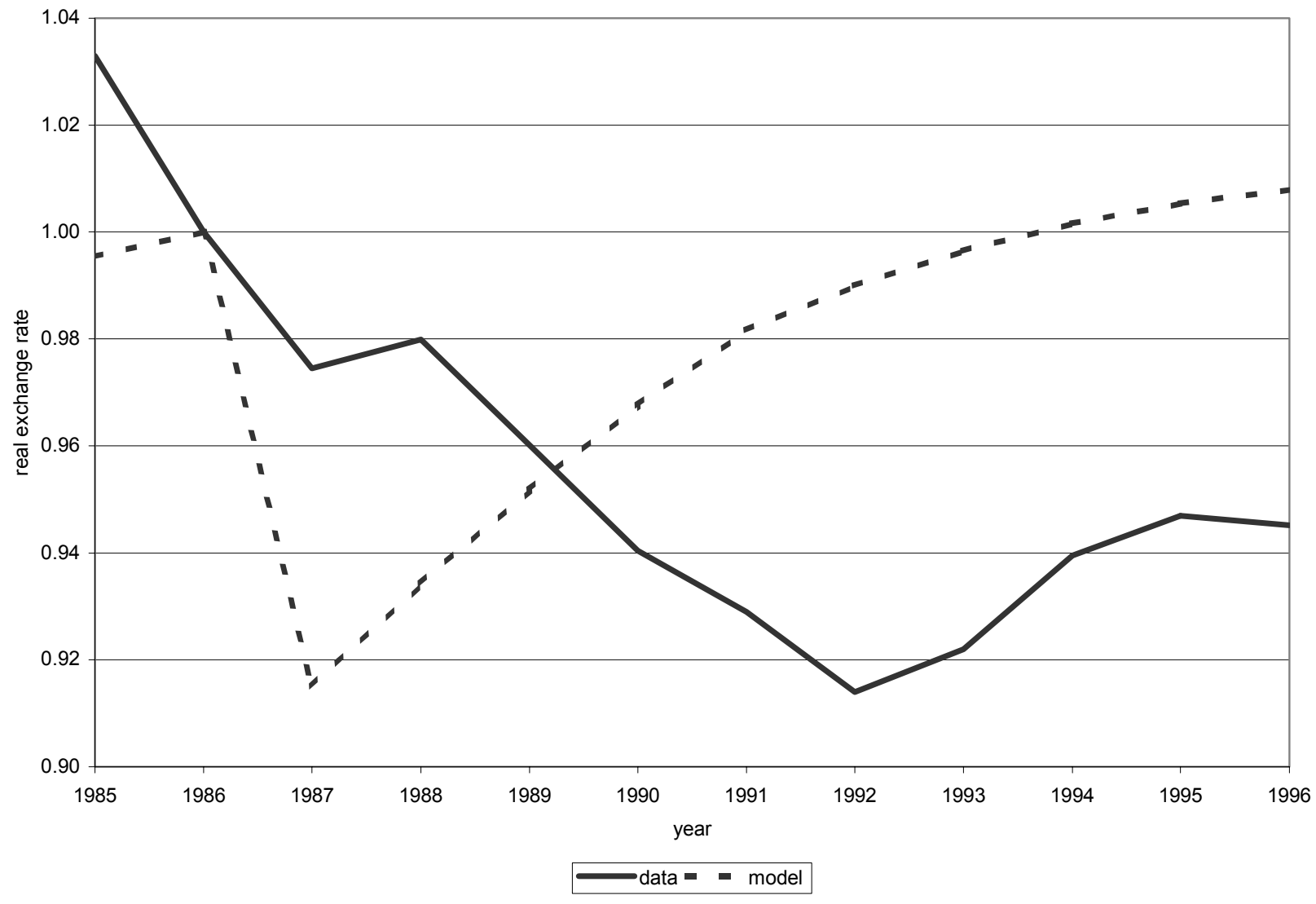

Figure 11: Model with capital and labor adjustment frictions - real exchange rate. 


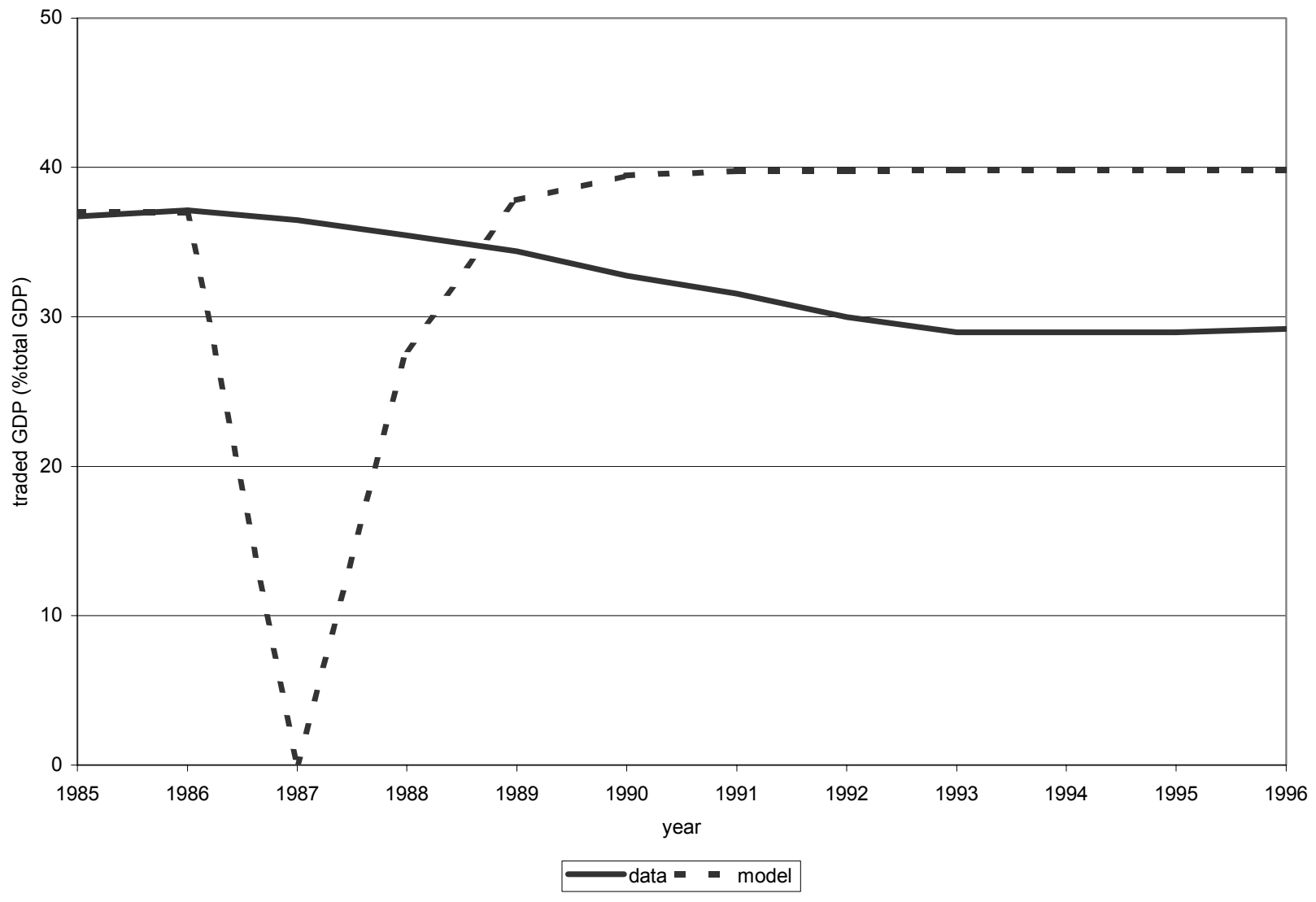

Figure 12: Basic model - traded output. 


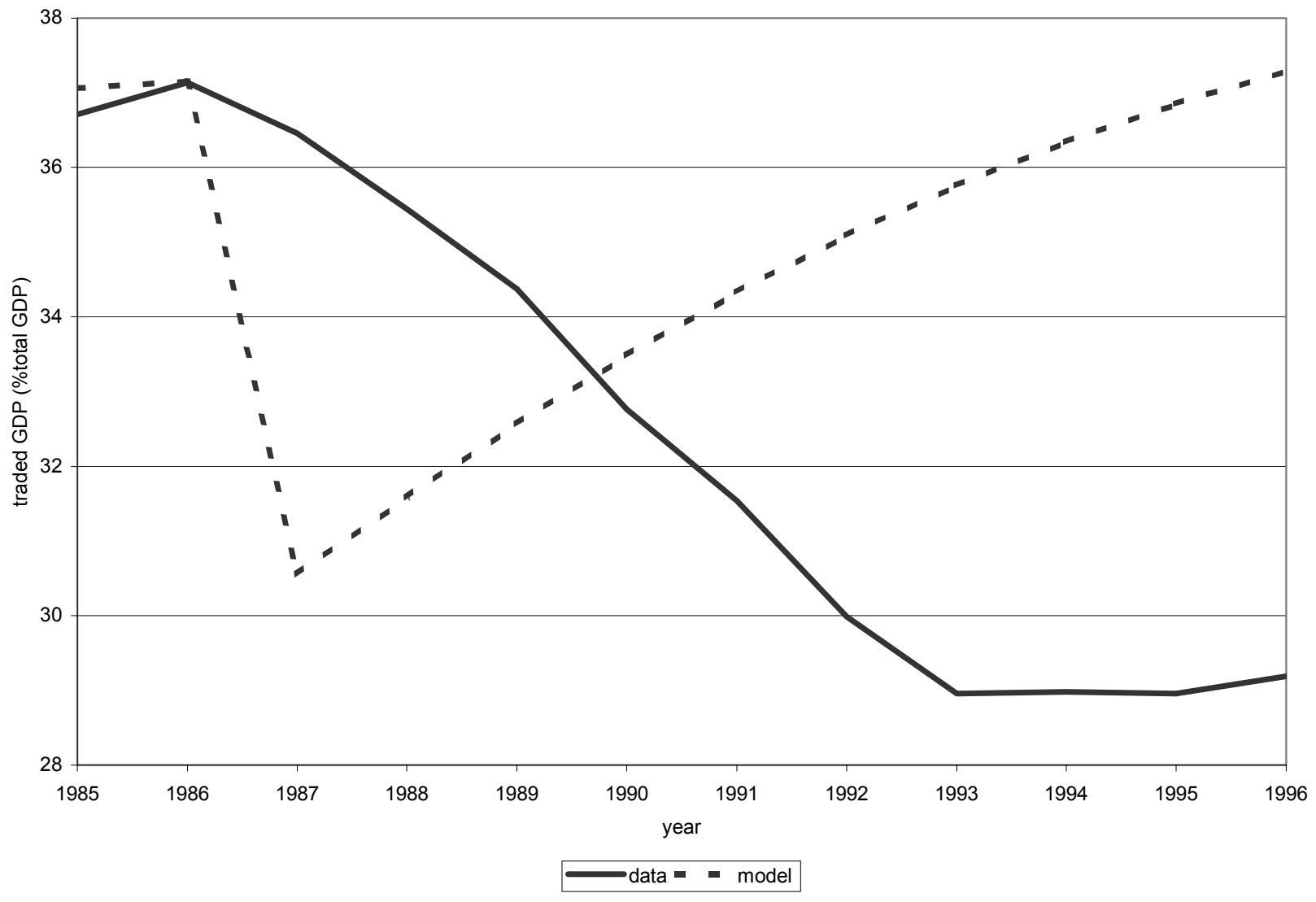

Figure 13: Model with capital adjustment frictions - traded output. 


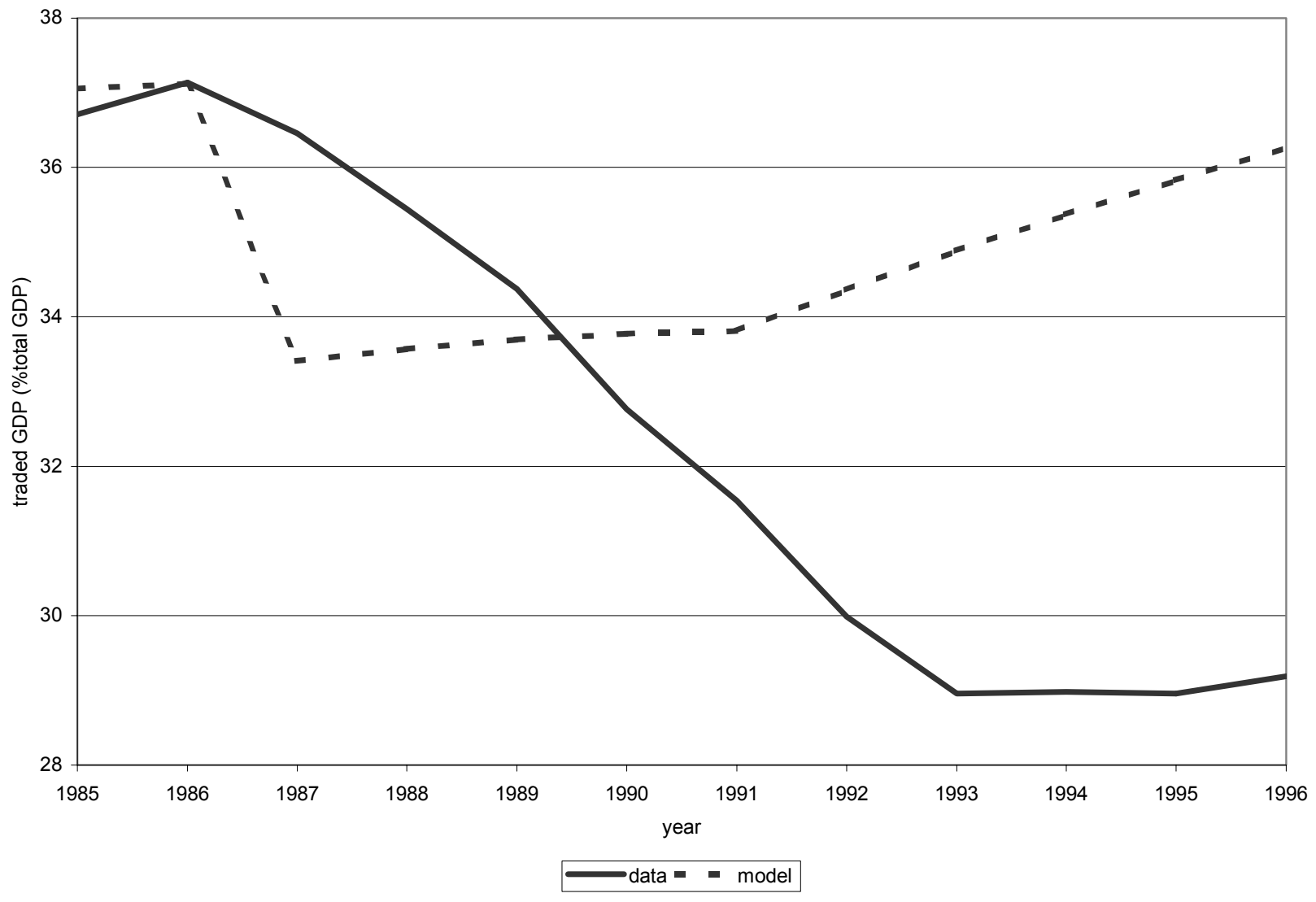

Figure 14: Model with capital and labor adjustment frictions - traded output. 


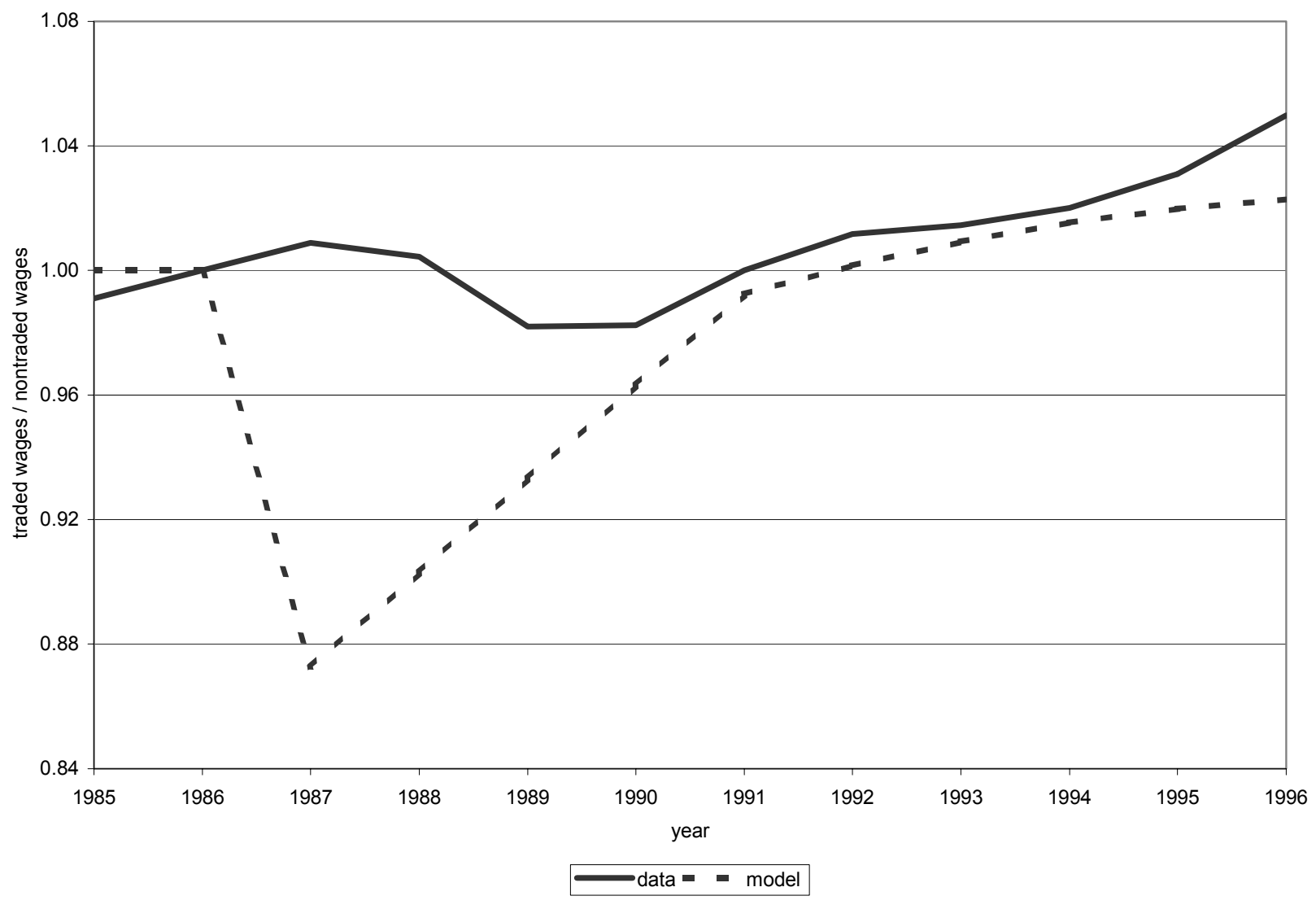

Figure 15: Model with capital and labor adjustment frictions - relative wages. 